\title{
Games judges don't play: predatory pricing and strategic reasoning in US antitrust
}

\author{
Nicola Giocoli*
}

The paper analyzes the last three decades of debates about predatory pricing in US antitrust law, starting from the literature that followed Areeda and Turner's 1975 landmark paper and ending in the beginning of this century, upon the Brooke 1993 decision. Special emphasis is given to the game-theoretic approach to predation and to the reasons why this approach has never gained attention in the courtroom. It is argued that, despite their mathematical rigor, the sophisticated stories told by strategic models to demonstrate the actual viability of predatory behavior fail to satisfy the criteria guiding court's decisions, in particular their preference for easy-to-apply rules. Predation cases are still governed by a peculiar alliance between Chicago-style price theory-which, contrary to game theory, considers predatory behavior almost always irrational-and

${ }^{*}$ Associate Professor of Economics, Faculty of Law, University of Pisa, via CollegioRioci 10, 56126 Italy. E-mail: giocoli@mail.jus.unipi.it

The paper was presented as Séminaire Cournot 2010 at the University of Strasbourg: I thank Sylvie Rivot and Herrade Igersheim for their invitation. I am also grateful for their useful comments to two anonymous referees, as well as to Francesco Guala, Ivan Moscati and the other participants at a MicroCafé Seminar at Bocconi University, Milan. Robert T. Masson provided helpful historical information. Salar Ghahramani, Alain Marciano, Robin Paul Malloy and Maurizio Mistri also commented on the paper at the STOREP 2010, HISRECO 2010 and HES 2010 conferences. Jennifer Windfeldt helped polish my English. Financial support from INET 2011 Grant "Free from what? Evolving notions of 'market freedom' in the history and contemporary practice of US antitrust law and economics" is gratefully acknowledged. I am of course responsible for any remaining mistakes. 
a Harvard-style attention to the operational side of antitrust enforcement.

$[\mathrm{N}] \mathrm{o}$ mere fact ever was a match in economics for a consistent theory (Milgrom and Roberts 1987, 195)

Strategic theories of predatory pricing are pristine theoretical existence proofs (Elzinga and Mills 2001, 2493)

We shall take into account of the institutional fact that antitrust rules are court-administered rules. They must be clear enough for lawyers to explain them to clients. They must be administratively workable and therefore cannot always take account of every complex economic circumstance or qualification. (then-Judge Stephen Breyer in Town of Concord $v$. Boston Edison Co., 915 F.2d 17, $1^{\text {st }}$ Circuit, 1990, at 22)

\section{IN TRODUCTION}

At the Paul Samuelson Memorial Session during the 2010 AEA meeting, his colleague and friend Robert Solow recalled that, when challenged by a skeptical MIT engineer to state a proposition in economics that was true but not obvious, Samuelson named the principle of comparative advantage. What if he had answered "predatory pricing", i.e., the proposition that by lowering price a firm may harm both competition and consumers? Would that be a legitimate answer?

That this proposition is far from obvious, and perhaps even counterintuitive, is a no-brainer, given that a price reduction is normally deemed beneficial for consumers and a sign of healthy competition. But is it also true? This requires answering two different sub-questions. First, is it possible that a price may indeed be so low that it harms competition and consumers? Second, is it possible that a profit-maximizing firm may rationally decide to charge such a low price?

The MIT engineer's reaction to Samuelson didn't go on record, but even if he agreed that the comparative advantage principle was at the same time a true but not an obvious proposition, he might have added a third requirement, namely, that the proposition also had practical relevance (which in that very case it clearly had). In the case of predatory pricing (PP hereafter), and assuming affirmative answers to the previous sub-questions, this would amount to asking whether actual firms ever undertake predatory behavior, and thus, whether $\mathrm{PP}$ is a real world phenomenon or just a theoretical construct. This third query is as relevant as the previous two, because PP impinges upon a very concrete activity, like antitrust enforcement. Indeed, the century-long and ongoing debate over PP has always focused on all 
three of the questions and on the different and sometimes conflicting answers that have been given throughout the years by economists, law scholars and judges.

This paper focuses on a recent phase of the debate, namely, from the publication of the highly influential Areeda and Turner in $1975^{1}$ to the beginning of this century. ${ }^{2}$ This is an extremely interesting period in all respects-theoretical, legal and historical-because it witnessed substantial changes in the way the three questions above have been answered in the US. In particular, I will cast light on the controversial relationship between strategic analysis and law enforcement. In a nutshell, when, how and why has modern game theory influenced the way US courts apply antitrust law to PP cases, if at all? I find this issue especially interesting not only per se, i.e., as a crucial ingredient to any historical reconstruction of the evolution of US antitrust law and economics, but more generally, because it may represent a useful lesson on the kind of features that make a formal economic model more likely to have an impact on the real world, via the reception of its main outcomes and prescriptions by judges and courts. This in turn may help foresee the future pattern of antitrust enforcement by US courts, including the Supreme Court, and especially on related subjects like the "hot" issue of predatory bundling.

The content of the paper is as follows. Section 1 contains a summary of the pre-1975 debate on PP. Section 2 deals with the first breaking point in our story, namely, Areeda and Turner's 1975 paper $^{3}$ and the reactions to it. Sections 3 and 4 cover the new gametheoretic methodology and the related predation stories developed since 1982. Section 5 is dedicated to whether antitrust courts should follow the strategic approach to PP. Sections 6 and 7 deal with the second watershed in our narrative, namely, the Supreme Court's Brooke decision that in 1993 effectively barred the strategic approach. ${ }^{4}$ Section 8 focuses on a recent, and largely unsuccessful, effort to renew the courts' interest in strategic predation. Lastly, section 9 takes on again the issue of why judges and courts have refused to "play the games" economists have bestowed upon them when investigating PP cases.

\footnotetext{
${ }^{1}$ P Areeda and D F Turner, Predatory Pricing and Related Practices under Section 2 of the Sherman Act, 88(4) Harv L Rev 697-733 (1975).

${ }^{2}$ I have covered the earliest phases of the debate in N Giocoli, When LOW is No Good: Predatory Pricing and US Antitrust Law (1950-1980), 18(5) Eur J Hist of Econ Thought 777-806 (2011).

${ }^{3}$ Areeda and Turner, 88(4) Harv L Rev 697-733 (cited in note 1) (1975 article).

${ }^{4}$ Brooke Group Ltd v Brown et Williamson Tobacco Corp, 509 US 209 (1993).
} 


\section{FROM THE “WILDS OF ECONOMIC THEORY" TOA “MEANINGFULAND W O R K A B L E” R ULE}

"The predatory price-cutter is one of the oldest and most familiar villains in our economic folklore." 5 This folklore dates back to a couple of early $20^{\text {th }}$-century famous antitrust cases, Standard Oil ${ }^{6}$ and American Tobacco. ${ }^{7}$ Both cases featured a large firm, the villain in the story, charged for bringing prices down to a point where no competitor could survive, thereby becoming a monopolist. These and the other cases of PP fell either below the Sherman Act §2's prohibition of monopolization or below the Robinson-Patman Act's ban of price discrimination.

For more than sixty years, US antitrust courts dealt with alleged predation episodes applying a common narrative captured by the following quotation:

"The pre-1975 legal standard for predatory pricing hinged on two factors-unfair use of pricing power against new entrants or smaller firms, and protection of long run market competitiveness viewed primarily in terms of market structure. Economic efficiency was not specifically articulated as a legal policy goal. [. . .] Unfairness was emphasized under the RobinsonPatman Act, while structural competiveness was stressed under the Sherman Act." 8

Thus, the two basic ingredients of any allegation of predatory behavior had to be the existence of the structural requirement of market power and the intention of unfairly exploiting a price reduction to increase or consolidate that power. Market power and predatory intent were the necessary features that antitrust courts had to detect in order to validate an accusation of predatory behavior.

US courts went on for decades inferring predation from dubious proofs of market power and exclusionary intent. If both requirements were met, a per se prohibition applied, leading to the automatic condemnation of the alleged predator. ${ }^{9}$ No special consideration was

\footnotetext{
${ }^{5}$ R.H Koller II, The Myth of Predatory Pricing: An Empirical Study 105 [1971] in Y Brozen (ed.), The Competitive Economy: Selected Readings 418-428 (General Learning Press, Morristown (NJ) 1975).

${ }^{6}$ Standard Oil Co of New Jersey v United States, 221 US 1 (1911).

${ }^{7}$ United States v American Tobacco Co, 221 US 106 (1911).

${ }^{8} \mathrm{~J}$ F Brodley and G A Hay, Predatory Pricing: Competing Economic Theories and the Evolution of Legal Standards, 66 Cornell L Rev 755-6 (1981).

${ }^{9}$ W E Kovacic, The Intellectual DNA of Modern US Competition Law for Dominant Firm Conduct: The Chicago/Harvard Double Helix, 1 Columbia Business L Rev 4, 43-46 (2007).
} 
given to the relationship between price and cost, i.e., courts did not feel obliged to check whether the low price was still above the predator's costs and thus whether the exclusionary effect-if any at allcould only work against less efficient, higher cost rivals, for whom such a price might well be below cost. Condemning a firm for predatory behavior in that case would, of course, generate an anti-competitive and inefficient outcome. This would amount to protecting inefficient competitors, rather than competition. Worse than that, an excessively strict enforcement of PP violations would risk, to use modern Industrial Organization (IO henceforth) jargon, chilling genuine competitive behavior, i.e., either condemning or discouraging normal competitive behavior in terms of welfare-improving price cuts. Indeed, the ghost of killing "good" competition has haunted the whole history of anti-PP enforcement and has been the underlying argument in all of its critiques.

The traditional legal approach was challenged in 1958 by a Chicago scholar, John McGee, who set out to establish two simple results. ${ }^{10}$ First, that by applying standard price theory it was possible to demonstrate that the classic story of PP was untenable. Second, that a price-theoretic assessment of the factual evidence in the most famous PP case to date, the 1911 Standard Oil, demonstrated that the condemnation of Standard Oil for predatory behavior had been largely unfounded. McGee's results laid the ground for the Chicago approach to PP, whose central idea-as in Robert Bork's classic presentation ${ }^{11}$ - has since been that profitable, below-cost pricing is at best a very infrequent, and probably impossible, business behavior. It follows that, in the words of another authoritative member of the Chicago School, "[a]ny attempt to administer a rule against predation entails a significant risk of condemning the outcome of hard competition. [. . .] If there is any room in antitrust law for rules of per se legality, one should be created to encompass predatory conduct"12

Despite being essentially fact-based, the most influential part of McGee's article was the theoretical one. ${ }^{13}$ What he and his generation of Chicagoans achieved was to establish price theory as the indispensable tool to check the validity of each story told to antitrust courts by either private plaintiffs or federal agencies. In the specific case of predation, price theory provided a couple of good reasons

${ }^{10}$ J S McGee, Predatory Price Cutting: The Standard Oil (NJ) Case, 1 J Law and Econ 137-169 (1958).

${ }^{11}$ See, for example, R H Bork, The Antitrust Paradox. A Policy at War with Itself ch 7 (Free Press, New York 1978).

${ }^{12}$ F H Easterbrook, Predatory Strategies and Counterstrategies, 48 (2) Univ of Chicago L Rev 336-337 (1981).

${ }^{13}$ McGee, $1 \mathrm{~J}$ Law and Econ 137-169 (cited in note 10). 
why the usual stories were probably unsound. Firstly, the observation that the predator usually suffered greater losses than the prey made it necessary for any dominant firm entertaining predation to have a "long purse" at his disposal; on the other side, this also made it possible for any prey to resist predation thanks to the financial help of outside creditors or customers. Thus, no theoretical grounds could exist for a PP allegation, unless both the actual existence of the predator's "deep pockets" and a specific reason for the prey's impossibility of finding support in capital or product markets were explicitly proven. Secondly, high barriers to entry were also required to protect the predator's recoupment phase from the possible arrival of new competitors or the re-entry of old ones. Again, the actual existence of these barriers had to be demonstrated if one wished to raise a convincing predation charge. Hence, price-theoretic analysis naturally led to an alternative story, one where PP was surely a rare and, perhaps, even an irrational strategy, so much so that price cuts and other allegedly predatory behaviors should always be considered as normal business practices, favorable to competition and market efficiency.

Yet, US antitrust courts did not follow McGee. As it turns out, the 1958 paper, so often quoted and debated in burgeoning legal and economic literature, was completely ignored by courts dealing with actual PP cases. ${ }^{14}$ Lacking an explicit endorsement by the Supreme Court, no lower level court dared raise doubts over the traditional legal story and the attached per se prohibition. The loose standards of market power and predatory intent thus survived within a legal environment that traced the rationale for condemning PP, not in protecting competition or promoting efficiency, but rather in defending a vague notion of fairness in the marketplace /cf. Brodley and Hay). ${ }^{15}$

That fairness, rather than efficiency, was the real yardstick was apparent in the 1967 Supreme Court's majority opinion in Utah Pie, not without reason considered "the most anticompetitive antitrust decision of the decade ${ }^{\prime \prime}{ }^{16}$ Fairness dictated that defendants in that

\footnotetext{
${ }^{14}$ Hence the statement by leading IO economist Luis Cabral that "One can hardly underestimate the influence of McGee's paper, both in economics scholarship and legal practice" is only half true. L Cabral, Predatory Pricing, in WA Darity Jr (ed), International Encyclopedia of the Social Sciences, 428-429 (Macmillan, vol $62 \mathrm{ed}$ 2008).

${ }^{15}$ Brodley and Hay, 66 Cornell L Rev 792 (cited in note 8).

${ }^{16}$ Utah Pie v Continental Baking Co, 386 US 685 (1967). The negative judgment is in Bowman. W S Bowman, Restraint of Trade by the Supreme Court: The Utah Pie Case, 455, in Y Brozen (ed), The Competitive Economy: Selected Readings, (General Learning Press, Morristown (NJ) (1975 [1967]).
} 
case had to be condemned as predators. Despite its being the leader in the Salt Lake City market for dessert pies, the single-plant and family-owned business Utah Pie deserved antitrust protection from the competition of the defendants, three big food conglomerates whose prices in Salt Lake City were lower than in the rest of the country, precisely because the latter were big food conglomerates, while the plaintiff was a family-owned business. In his dissent, Justice Stewart ". . . Utah Pie's monopolistic position was protected by the federal antitrust laws from effective price competition": the archetype of using antitrust law to defend a competitor, rather than competition. ${ }^{17}$

Utah Pie is simply the most prominent example of how US courts continued to mishandle PP cases during the 1960s and 1970s, by still focusing on vague notions of "harm to competitors", "predatory intent" and "ruinous competition", while paying little attention to efficiency issues. Another Supreme Court's decision mirroring the same legal attitude came one year earlier, in the Grinnell case. $^{18}$ There, the Court declared that Sherman Act $\S 2$ violations called for two elements, namely, the possession of monopoly power and a conduct requirement, that is, ". . . the willful acquisition or maintenance of that power as distinguished from growth or development as a consequence of a superior product, business acumen, or historic accident."19 Again, a vague notion like "willfulness" was called into play. Taking "willful" as synonymous of "intentional", the application of the Grinnell dictum could only cause trouble to US courts, given the obvious circumstance that every firm willfully acquires or maintains its market power, that is to say, even when it does so via "business acumen" or a "superior product". ${ }^{20}$

Both Grinnell, with its focus on intent, and Utah Pie, with its emphasis on the defense of competitors rather than competition, were symptomatic of the distance separating that branch of antitrust law from proper economic analysis. To cap this trend came the Topco decision, ${ }^{21}$ where the Supreme Court penned an anathema against theoretical economics: "Should Congress ultimately determine that predictability is unimportant in this area of the law, it

${ }^{17}$ Utah Pie, 386 US at 706.

${ }^{18}$ US v Grinnell Corp, 384 US 563 (1966).

${ }^{19}$ Id at $570-1$.

${ }^{20} \mathrm{G} J$ Werden, Next Steps in the Evolution of Antitrust Law: What to Expect from the Roberts Court 5(1) J of Competition L \& Econ 49-74, 68-9 (2009). D.C. Circuit in its Microsoft opinion has stated that the conduct element of the monopolization offense should not relate to the defendant's intent or state of mind. See US v Microsoft Corp, 253 F3d 34, 59 (DC Cir 2001).

${ }^{21}$ United States V Topco Assocs Inc, 405 US 596 (1972). 
can, of course, make per se rules inapplicable in some or all cases, and leave courts free to ramble through the wilds of economic theory in order to maintain a flexible approach." 22 This jurisprudential attitude led to a very high percentage of condemnations in predatory cases at the level of federal courts. Until the mid-1970s three out of four PP trials at federal level were decided against the defendant. ${ }^{23}$ In the same period, US federal agencies behaved aggressively against price cuts made by dominant firms. The Department of Justice did not hesitate to bring criminal charges against alleged predators during the whole of the 1960s. And in a 1977 public address Attorney General Griffin Bell could still announce his willingness to undertake criminal enforcement against PP aimed at destroying competitors. ${ }^{24}$ In short, the hostility of US antitrust courts and agencies against those price cuts made by dominant firms remained untouched well into the 1970s, as if McGee's paper had never been written. ${ }^{25}$

Yet, the 1958 paper had been written, and, after it, also a wealth of new economic literature. Here price theory had been applied either to strengthen McGee's results or to defend the rationality of predatory behavior in much sounder terms than those used by US courts, i.e., in terms of theoretically sophisticated stories where predation might well be profitable. ${ }^{26}$ In the eyes of those scholars who did believe that PP potentially was a serious offense, but who, at the same time, did not want the per se illegality of predation to turn into a de facto prohibition of every legitimate kind of price competition, the situation in the early 1970s was troublesome. On the one hand, we had a populist application of the PP offense by antitrust courts, founded upon very weak legal stories that had led to a list of wrong or at least very debatable rulings. On the other hand, we had several price-theoretic stories whose implications ranged from Chicago's suggested abolition of the predatory offense to a higher risk of legal mistakes. The latter stemmed from the courts' necessity "to ramble

\footnotetext{
${ }^{22}$ Id at 612 (emphasis added).

${ }^{23}$ See P Bolton, J F Brodley and M H Riordan, Predatory Pricing: Strategic Theory and Legal Policy, 88 Georgetown L J 2253 (2000). In an oft-quoted study, Koller The Myth of Predatory Pricing (cited in note 5) listed 123 federal PP cases, of which 95 had ended with the condemnation of the predator.

${ }^{24}$ Quoted by Koller, The Myth of Predatory Pricing 45 (cited in note 5).

${ }^{25}$ The first decision by a US court ever to mention McGee has been Matsushita Zenith Ratio Corp, 475 US 574 0986, on which see below, Section 7.

${ }^{26}$ This literature is analyzed in Giocoli, 18(5) Eur J Hist of Econ Thought (cited at note 2). For a broader, though debatable, assessment of McGee's influence see J A Dalton and L Esposito, Standard Oil and Predatory Pricing: Myth Paralleling Fact, 38 Rev Industrial Org 245-266 (2011).
} 
through the wilds of economic theory" in order to verify the applicability of sophisticated economic arguments.

The deadlock was broken by two Harvard law scholars, Donald F. Turner and Phillip E. Areeda, whose paper in the 1975 Harvard Law Review became an instant classic. ${ }^{27}$ Their main idea was that, rather than struggling to reconstruct the plausibility of one or the other predatory stories available in the literature, courts should apply a straightforward rule and draw the consequences of the result. In place of a complex and increasingly controversial doctrine, Areeda and Turner suggested a simple, bright-line principle, directly derived from basic price theory and discriminatory enough to allow the identification of real predatory behavior while avoiding the risk of chilling genuine competition. In the authors' words, "[i]n this paper we will attempt to formulate meaningful and workable tests for distinguishing between predatory and competitive pricing by examining the relationship between a firm's costs and its prices." 28 Their rule aimed, on the one side, at giving specific content to the otherwise generic and arbitrary expression "below cost pricing" that was often encountered in PP cases and, on the other, at being "meaningful and workable", i.e., easily applicable by a court. As I detail below (see section 7), the latter goal constitutes the trademark of the Harvard approach to antitrust. As Justice Breyer put it in his tribute to Donald Turner, Turner's "basic point of view" was that "[a]ntitrust policy cannot rest upon a laundry list of fifty or a hundred different factors. ${ }^{29}$ In order to achieve its main goal, namely, the protection of the competitive process, law enforcement had rather to be based on "soundly based rules using a few key factors that bench and bar can understand and that courts and agencies can administer." 30

But which of the various notions of cost should become the threshold for the new rule? In Areeda and Turner's short run static

\footnotetext{
${ }^{27}$ At the time Donald Turner was still the leading figure of the duo: a Harvard PhD in economics (in 1947) and law professor from 1954 to 1979, he authored with Carl Kaysen an influential text on antitrust law and economics and headed the Antitrust Division in the US Department of Justice from 1965 to 1969, where he created the position of Special Economic Assistant to the Assistant Attorney General, the top job in US federal administration for an antitrust economist. With Phillip Areeda (another Harvard law professor and outstanding antitrust scholar), he also authored the monumental. P Areeda and D F Turner, Antitrust Law: An Analysis of Antitrust Principles and their Application, (7 vols Little, Brown \& C, Boston 1978). Details on Areeda and Turner's lives and contributions can be found in the Winter 1996 memorial issue of the Antitrust Bulletin.

${ }^{28}$ Areeda and Turner, 88(4) Harv L Rev 697-733 at 699-700 (1975 article) (cited in note 1).

${ }^{29}$ S G Breyer, Donald F Turner, 41 Antitrust Bulletin 725-727 at 726 (1996).

${ }^{30}$ Id at 726.
} 
model with linear costs, the answer came directly from price theory: the relevant notion had to be marginal cost. Hence, no price equal or greater than short run marginal cost could ever be considered predatory, while any price below that level should be presumed so. ${ }^{31}$ Yet, this version of the rule clashed with the authors' operational purpose. Actual courts would in fact find themselves in trouble if called to estimate a firm's marginal cost. Keeping in mind their goal of being "meaningful and workable", Areeda and Turner offered, as a solution; to replace in actual litigations marginal cost with a proxy, average variable cost (AVC hereafter). Hence, the final version of Areed a and Turner rule (ATR henceforth):

"we conclude that: (a) A price at or above reasonably anticipated average variable cost should be conclusively presumed lawful. (b) A price below reasonably anticipated average variable cost should be conclusively presumed unlawful." ${ }^{\prime 32}$

It was in this version that, to paraphrase Keynes's famous dictum, the ATR "conquered [US courts] as completely as the Holy Inquisition conquered Spain" ${ }^{\prime \prime 3}$ And it is from this conquest that our narrative proceeds.

\section{PLA Y ING B Y THE RULE}

It is hard to say whether the ATR had the largest effect on US antitrust courts or on antitrust literature, as it was huge for both. As far as courts are concerned, the ATR is a rare instance of an economic idea that immediately and significantly affected law enforcement. The rule radically changed the courts' attitude towards PP: from a percentage of victories in PP litigations of over $75 \%$ (as calculated by Koller), ${ }^{34}$ plaintiffs' success rate fell to less than $20 \%$ between 1975-1993, and in particular to $0 \%$ in the five years immediately following the publication of Areeda and Turner's paper-that is to say,

\footnotetext{
${ }^{31}$ Areeda and Turner, 88(4) Harv L Rev 697-733 (1975 article) (cited in note 1). Note that the rule directly aimed at distinguishing pro-efficiency from anti-efficiency price cuts (every price below marginal cost being necessarily welfare-reducing), but neglected the issues of whether predation was profitable and whether it was a real world phenomenon (our second and third questions in the Introduction). In other words, Areeda and Turner took for granted that the court had an adequate reason to undertake the inquiry and apply the rule. Easterbrook, 48 (2) Univ of Chicago L Rev 276 (cited in note 12).

${ }^{32}$ Areeda and Turner, 88(4) Harv L Rev at 733 (cited in note 1).

${ }^{33}$ Keynes, The General Theory of Employment, Interest and Money at 32 (MacMillan, London 1973 [1936]),

${ }^{34}$ Koller, The Myth of Predatory Pricing 45 (cited in note 5).
} 
no plaintiff's victory in PP cases went on record from 1975 to $1980 . .^{35}$ The paper has been quoted by more than 100 antitrust courts from 1975 to $2000,{ }^{36}$ and six of these courts did not even let the Harvard Law Review's ink dry before applying of this new rule, as they did so between early 1975 and mid-1977. ${ }^{37}$ Thus, it is an euphemism to say that ATR was swiftly embraced by US courts and it is hardly an exaggeration to claim that the rule created a situation of de facto per se lawfulness of every price cut, turning PP litigations, as a commentator put it, into "a defendant's paradise"

Why did US courts so eagerly endorse the ATR? A preliminary answer may be found in the above-mentioned dire straits of PP enforcement from the late 1960s to early 1970s. Attacked on many fronts for the theoretical weakness-if not outright inconsistencythe stories underlying their analysis of in PP cases, courts seemed all too happy to adopt a simple, highly operational rule that exhibited the prestigious label of price theory, itself a warranty that, apart from material mistakes in calculating prices and costs, no decision based on it could ever be accused of being devoid of solid theoretical foundations. Hence, the immediate success of ATR revealed a clear preference by antitrust courts for rule-based decisions over storybased ones. ${ }^{39}$

3.1 The ATR impact on the literature was, if possible, stronger and faster than the courts. A fierce debate began with big names involved, such as Mike Scherer, Richard Posner, Oliver Williamson, Robert Bork, Dick Schmalensee, Alvin Klevorick and William Baumol, all of whom published relevant contributions between 1976 and $1979 . .^{40}$ These were followed in the next couple of years by survey

\footnotetext{
${ }^{35}$ See Bolton et al, 88 Georgetown L J 2253-54 (cited in note 23).

${ }^{36}$ Actually, 109 times out of the 448 significant PP cases in the same period (the term "significant" meaning those cases where predation is referred to in either the case overview or the core terms). The pct. of hits is a stunning $24 \%$. Source: Lexis.

${ }^{37}$ The rule immediately affected the DOJ as well. Already in 1976 the Department dismissed a big antitrust case precisely because it fell short of satisfying the marginal/ average variable cost test. O E Williamson, Predatory Pricing: A Strategic and Welfare Analysis, 87(2) Yale L J 284-340, 285 fn 5 (1977).

${ }^{38}$ Williamson, 87(2) Yale L J at 305 (cited in note 37).

${ }^{39}$ We will return to this issue below, Section 8.1 .

${ }^{40}$ F M Scherer, Predatory Pricing and the Sherman Act: A Comment 89(5) Harvard L Rev 869-890 (1976); R A Posner, Antitrust Law Ch 7 (Chicago 1976); R A Posner, The Chicago School of Antitrust Analysis 127 U Pa L Rev 925-948 (1979); Williamson, Yale L J at 284-340 (cited in note 37); Bork, The Antitrust Paradox at ch 7 (cited at note 11); R Schmalensee, On the use of Economic Models in Antitrust: The ReaLemon Case 127(4) U Pa L Rev 994-1050 (1979); P L Joskow and A K Klevorick, A Framework for Analyzing Predatory Pricing Policy, 89(2) Yale L J 213-270 (1979);
} 
articles on PP theory and policy, such as those authored by McGee, Brodley and Hay and Easterbrook. ${ }^{41}$ It goes beyond the limits of the present paper to analyze this post-ATR literature in detail. The rest of this section will summarize its main threads and outcomes.

As far as the former are concerned, two major issues were tackled. First of all, the rule vs. story dichotomy of the contributors, though critic of Areeda and Turner's specific solution, embraced their overall goal of achieving a "meaningful and workable" rule, capable of replacing all the dubious predatory stories told by pre-1975 courts. On the contrary, other participants in the debate were against what they considered a gross simplification of a tricky issue, and pressed hard for a return to a story-based approach, i.e., in antitrust jargon, for making recourse to a full rule of reason inquiry. A third position was held by those scholars who argued that PP was hardly an issue at all and thus were in a sense neutral with respect to the rules vs. stories debate they believed that every rule or story, if rigorous enough, would inevitably reveal that predation could never be rational business behavior.

The champion of the rule of reason approach was Mike Scherer, who was actually the first to react against Areeda and Turner's paper. ${ }^{42}$ This is remarkable because Scherer also came from Harvard University-that is to say, authored by a Harvard antitrust economist dismissing an argument by two prominent Harvard antitrust lawyers. Maybe the infeud had to do partly with the defense of the economists' own territory, ${ }^{43}$ but the main reason behind it was Scherer's prescience of the inevitable outcome of ATR in the courts, namely, the de facto legalization of every price cut by market leaders-something no supporter of Harvard's structure-conduct performance mantra could digest. Hence, he argued that it was both unrealistic and analytically incorrect to apply a simple short-run price-cost rule for assessing whether a price be predatory. Only a complete examination of facts, intent and market structure ${ }^{44}$-i.e.

W J Baumol, Quasi-permanence of Price Reductions: A Policy for Prevention of Predatory Pricing, 89(1) Yale L J 1-26 (1979). Remarkably, most of this literature appeared in law, not economics, journals.

${ }^{41}$ JS McGee, Predatory Price Revisited, 23(2) J Law \& Econ 289-330 (1980); Brodley and Hay, 66 Cornell L Rev 738-803 (cited in note 8); Easterbrook, 48 (2) Univ of Chicago L Rev (cited in note 12).

${ }^{42}$ Scherer, Harvard L Rev 869-890 (cited in note 40).

${ }^{43}$ Indeed Scherer began his attack by complaining that Areeda and Turner simply did not know price theory enough to offer a rigorous argument. Scherer, Harvard L Rev 869 (cited in note 40).

44 " $[\mathrm{A}]$ thorough examination of the factual circumstances accompanying the monopolist's alleged predatory behavior, how the monopolist's officials perceived the probable effects of its behavior (i.e., intent), and the structural consequences actually flowing from the behavior" Id at 890 . 
a full-blown rule of reason methodology-could save courts from making the wrong decision.

In their reply, Areeda and Turner pointed out that long run welfare effects-of the kind that had to be evaluated for applying the rule of reason-are intrinsically speculative and indeterminate, so much so that no suitable administrable rule could be formulated to give them recognition. Scherer's checklist of relevant features to be assessed in order to validate a price cut could not be realistically used, either ex ante by a monopolist wishing to determine the legal floor for its pricing policy, or ex post by a court. Hence, in the very spirit of their 1975 paper, they concluded that "Scherer's constructs for determining what price will maximize long-run welfare have no operational utility for antitrust law purposes. [. . .] We adhere to our position that a test which is reasonably determinable and which plainly maximizes short-run welfare is the most sensible solution." ${ }^{\prime 45}$

Scherer had failed to understand that Areeda and Turner never intended to deny that, say, even an above-cost price set by a dominant firm might well be harmful for competition and welfare. Their whole point was that, given the institutional limitations of courts and agencies, there was no reliable way to condemn such behaviour without chilling pro-competitive conduct. Indeed, calling into play as an essential ingredient of law enforcement elements like the defendant's intent "was precisely the evil that Areeda and Turner were seeking to avoid, and the evil committed by earlier decisions." 46

Yet Scherer's suggestion found more favorable reception in authors such as Dick Schmalensee or Alvin Klevorick. ${ }^{47}$ The former argued that, absent any simple predation model with a clear

${ }^{45}$ Areeda and D F Turner, Scherer on Predatory Pricing: A Reply, 89(5) Harv L Rev 891-900, at 897 (1976). Curiously, these critiques were echoed by Chicago champion Robert Bork, who deemed Scherer's proposal simply unworkable. In reference to Scherer's list of features on which courts were called to inquiry, Bork claimed that: "There could hardly be drawn a list of criteria less fit for judicial employment. Those items on the list that would not be altered by the monopolist's knowledge of the rules are unknowable by either courts or economists. It is a mistake to suppose that all of the questions posed by in abstract geometric representation of demand and cost phenomena can usefully be addressed in a court proceeding." Bork, The Antitrust Paradox at 155 (cited in note 11). In his rejoinder to Areeda and Turner, Scherer acknowledged that speculative elements were inescapable in his suggested procedure, but also remarked that speculation was not new to antitrust adjudication, nor were the information requirements as big as implied by Areeda and Turner's reply. F M Scherer, Some Last Words on Predatory Pricing 89(5) Harv L Rev 901-903 (1976).

${ }^{46} \mathrm{H}$ Hovenkamp, The Areeda-Turner Treatise in Antitrust Analysis, 41 Antitrust Bulletin 815-842, 835 (1996).

${ }^{47}$ Schmalensee, 127(4) U Pa L Rev 994-1050 (cited in note 40); A K Klevorick, The Current State of the Law and Economics of Predatory Pricing, 83(2) Am Econ Rev, Papers and Proceedings 162-197 (1993). 
test, the only two robust approaches to PP were either the "hands off", Chicago-style approach-i.e., to drop the conduct from the list of proscribed practices-or Scherer's rule of reason, this being "the only one economically defensible general policy choice. ${ }^{48}$ The latter, in an influential paper with Paul Joskow, suggested a two-tier rule of reason approach, premised on the circumstance that no straightforward rule based only on behavioral considerations (such as the ATR, but also the rules by Williamson or Baumol, on which see below) could provide a proper means for distinguishing amongst different market situations, and thus minimizing judicial errors. Only their two-tier rule of reason-which required a Harvard-style structural analysis in the first stage and a behavioral inquiry in the second stage, but only for those cases where structural analysis yielded a reasonable expectation that the predator might have actually exploited its monopoly power-could combine sufficient flexibility in response to market specificities with the minimization of implementation costs. ${ }^{49}$

Another authoritative endorsement of Scherer's view came in the conclusions of Joseph Brodley and George Hay's 1981 survey. ${ }^{50}$ They acknowledged that "[p]rior to 1975 , predatory pricing was a loosely structured, somewhat opaque area of law in which the generality of the legal standard left room for the exercise of judicial discretion." 51 Still, a few years' experience with ATR had convinced Brodley and Hay that, due to "[t]he adoption of a marginal cost pricing rule by several courts [. . .] the range of judicial discretion was seriously confined.," 52 , so much so that "consistent litigation losses by plaintiffs demonstrated that for all practical purposes a predatory pricing plaintiff could not meet the standard imposed by the marginal cost rule." ${ }^{53}$ As a consequence, the ATR ". . . holds dominant firm pricing per se legal." This was unacceptable because "[m]ore recent economic literature [. . .] fails to demonstrate a consensus justifying the dismissal of predatory pricing as irrational behavior" ${ }^{\prime 54}$ and because "the courts did not purport to adopt the marginal cost pricing rule as a device for eliminating the predatory pricing offense and estab-

\footnotetext{
${ }^{48}$ Schmalensee, 127(4) U Pa L Rev at 1027 (cited in note 40).

${ }^{49}$ Joskow and Klevorick, 89(2) Yale L J at 213-270 at 243 (cited in note 45).

${ }^{50}$ Brodley and Hay, 66 Cornell L Rev 738-803 (cited in note 8). Hay was chief economist at the US Department of Justice from 1973 to 1980 . He is credited with having played a major role in convincing the $\mathrm{DOJ}$ to hire "real" (i.e., $\mathrm{PhD}$ ) economists in order to apply "real" economic theory to antitrust issues (R.T. Masson, personal communication, April 21, 2009).

${ }^{51}$ Brodley and Hay, 66 Cornell L Rev 738-803 at 792 (cited in note 8).

${ }^{52}$ Id at 793.

${ }^{53} \mathrm{Id}$.

${ }^{54} \mathrm{Id}$.
} 
lishing the per legality of dominant firm pricing." 55 The authors endorsed a rule of reason solution and provocatively asked: "do not all of the preceding considerations suggest a renewed emphasis on the values and insights inlaid in long-standing judicial experience, built upon case-by-case adjudication, and on the advantage of incremental policy change, achieved gradually and with opportunity for self-correction?" 56

The reason I have given so much room to Scherer's position in the debate is that his views anticipated one of the main outcomes of the subsequent game-theoretic literature on predation, namely, the impossibility of identifying a so-called "bright line standard", i.e., a simple rule capable of discerning with high reliability when a given price/quantity pair set by a firm could be deemed predatory. As I explain below, applying strategic reasoning to PP forces plaintiffs to devise a plausible story explaining why the available facts constitute evidence of predatory behavior. Though game theory suggests that all plausible PP stories have to fall within one or the other of a few general categories, a court will always have to examine the soundness of the specific story offered by the plaintiff, i.e., to undertake a rule-of-reason scrutiny. In short, Scherer's rule of reason and game-theoretic reasoning share a hostility towards the application of simple, mechanical rules and a clear inclination for careful, caseby-case analysis.

3.2 Even the opposite side in the post-ATR debate is more interesting for its background and general implications than for its specific suggestions. There we find those who remained faithful to Areeda and Turner's message, yet argued for a different and better rule. The list of alternatives is quite long, the main ones being the rules suggested by the likes of Richard Posner, who argued that, since PP only caused trouble when a less efficient predator killed a more efficient rival, a price should be automatically considered exclusionary if and only if it had been set to exclude from the market an equally or more efficient competitor; ${ }^{57}$ Oliver Williamson, who focused on entry deterrence and claimed that an output, rule made more economic sense than a price one, in particular a rule forbidding a market leader to expand its short run output following a rival's entry, regardless of the price being above $\mathrm{AVC}_{;}^{58}$ and William Baumol, whose quasi-permanent price cut rule left the market leader free to

${ }^{55} \mathrm{Id}$.

${ }^{56}$ Id at 794.

${ }^{57}$ Posner, Antitrust Law at 188 (cited in note 40); Posner, $127 \mathrm{U} \mathrm{Pa} \mathrm{L} \mathrm{Rev} \mathrm{at}$ 939-944 (cited in note 40).

${ }^{58}$ Williamson, Yale L J at 334 (cited in note 37 ). 
cut prices following entry, but forbade him to re-raise the price in case the entrant left the market. ${ }^{59}$ What is really remarkable in these rules is not their specific content, but the kind of analysis, that supported them. Everyone recognized that the major fault in Areeda and Turner's analysis was their neglect of the strategic and intertemporal character of predatory behavior-a critique also shared by Scherer and the other supporters of the rule of reason approach, but more biting when made by scholars endorsing Areeda and Turner's operational urge.

The author who most emphasized this oversight in Areeda and Turner's 1975 article was Oliver Williamson. His 1977 contribution to the debate may be taken as the clearest exposition of the strategic and intertemporal aspects of PP before the advent of formal game theory. ${ }^{60}$ His model explicitly acknowledged: i) that predation could be used for entry deterrence as much as for the elimination of existing rivals; ${ }^{61}$ ii) that the standard notion of "sacrifice profits now for higher profits tomorrow" necessarily entailed a kind of strategic reasoning and had to be explicitly modeled in an intertemporal setup; ${ }^{62}$ iii) that PP could be used strategically as a signal to deter future entry; iv) that, crucially, the market leader might strategically perform some pre-entry actions, like building an excess capacity, which aimed at preempt entry itself (a point for which Williamson recognized his debt to Michael Spence's formal model of pre-entry strategic choices ${ }^{63}$; and $v$ ) that the leader's strategic adaptation to the law had also to be considered when devising a rule aimed at addressing predatory behavior. Nonetheless, Williamson still endorsed Areeda and Turner's operational goal, while rejecting Scherer's proposal. ${ }^{64}$

${ }^{59}$ Baumol, 89(1) Yale L J at 1-26 (cited in note 40). We may add the second stage of Joskow and Klevorick's two-tier approach. The authors suggested that courts adopt for that stage both the basic AVC version of the ATR, as a quick check of predation, and a total cost standard, whereby a price should be deemed predatory if less than average total cost (ATC hereafter) or, in case of multi-product firms, average incremental cost (AIC hereafter). Joskow and Klevorick, 89(2) Yale L J at 245 and fns (cited in note 40). AIC it had been first proposed in Baumol, 89(1) Yale L J at 9 fn 26 (cited in note 40$)$.

${ }^{60}$ Williamson, Yale L J at 284-287(cited in note 40).

${ }^{61}$ More than that: according to Williamson, specific examples could be built where PP was seemingly unprofitable with respect to the exclusionary goal and yet fully rational in view of the entry deterrence purpose.

${ }^{62}$ This was also the spirit of Baumol's pricing rule, which was explicitly addressed at destroying the "low profits now, higher profits tomorrow" rationale of PP. Baumol, 89(1) Yale L J at 5 (cite in note 40).

${ }^{63}$ A M Spence, Entry, Capacity, Investment and Oligopolistic Pricing, 8 Bell J Econ 534-544 (1977).

${ }^{64}$ This in a long footnote where he argued that following Scherer would entail replacing antitrust enforcement with a sort of market regulation by a price commission: 
As previously noted, Williamson rule looked at the leader's output and imposed that he abstains from increasing his quantity following a rival's entry. The rule clearly aimed at neutralizing the leader's threat to make recourse to his pre-entry-built excess capacity in order to flood the market and thus push the price below the level any entrant would find sustainable. This would make the leader's (socially inefficient, but privately long run profitable) choice of building an excess capacity irrational in the first place. Williamson also noted that ATR could not prevent, or prohibit, this kind of preentry behavior, as long as the price following post-entry output expansion was still above the leader's marginal or average variable costs. It followed that, despite Areeda and Turner's claims, the ATR was unable to warrant social efficiency both before and after entry. ${ }^{65}$

In view of the later history of PP law and economics, the most remarkable outcome of the intense debate following Areeda and Turner 1975 was precisely the emphasis on the strategic and intertemporal features of PP. This was not entirely novel, because similar considerations had also been raised during the 1960s and the early 1970s debate stemming from McGee's work. ${ }^{66}$ But never before had the strategic and intertemporal character of predatory behavior been more clearly revealed than in Williamson's paper. Moreover, this literature explicitly made the point that only by focusing on these features could the rationality of PP be demonstrated. In other words, giving full weight to strategic and intertemporal aspects was the necessary, and often also sufficient, condition to prove that PP might well be a profitable business strategy and so could really happen in the real world, especially if left unchallenged by antitrust law. Given that ATR could not handle the strategic and intertemporal features of PP, some of the authors in the post-ATR debate aimed at devising new and better rules to fill in the gap, while others denied that any simple rule could ever work. In short, at the end of the 1970s everyone involved in the theoretical debate shared the notion that only a properly constructed story, with explicit room for strategic and intertemporal elements, might justify the existence of $\mathrm{PP}$ as an antitrust violation.

\footnotetext{
"Rather than slip inadvertently into a regulatory posture-which, experience discloses, is typically hostile toward competition - antitrust is better advised to seek simple rules enforceable in court." Williamson, Yale L J at 288, fn 16 (cited in note 40).

${ }^{65} \mathrm{Id}$ at 335.

${ }^{66}$ The most "strategically oriented" paper had been Yamey's 1972 article. B S Yamey, Predatory Price Cutting: Notes and Comments, 15(1) J L Econ 129-142 (1972). See Giocoli, 18(5) Eur J Hist of Econ Thought at 77-806 (cited in note 2) for more details.
} 
3.4 Even the authors in the Chicago tradition could not avoid dealing with the strategic and intertemporal features of PP. For example, having recognized that McGee himself had neglected the strategic considerations, Richard Posner concluded that because of this omission, "it is not surprising that the Chicago school should not have been particularly concerned with predatory pricing. Eliminate strategic considerations, and it becomes impossible to construct a rational motivation for predatory pricing without assuming (very uncongenially to a Chicagoan) asymmetric access to the capital markets for financing a period of below-cost selling. But to ignore strategic considerations is not satisfactory." ${ }^{\prime \prime 7}$ Thus, all Chicagoans contributing to the post-ATR debate had at least to take position with respect to the role played by strategic and intertemporal elements, if only to dismiss their relevance.

Think of Bork's 1978 critiques against Scherer's proposal. ${ }^{68}$ In these words one may read a leitmotif of the Chicago approach, not only to PP, but to antitrust enforcement in general, namely, the idea that courts will never have the amount of information required to properly perform a rule of reason analysis without risking to commit serious mistakes. This critique applies to the rule of reason, but also-indeed, more forcefully-to the kind of stories proposed in the post-ATR debate, as even those stories may well be considered a manifestation of the "abstract geometric representation of demand and cost phenomena. ${ }^{\prime \prime 69}$ Or think of McGee's reassessment of predatory pricing where, while defending what he himself called the "diehard Chicagoan position" according to which attempts at predation "have been rare, and [. . .] successful attempts will be found to be still rarer.", ${ }^{70}$ he claimed that if a workable rule was ever to be called forth, it had to be a cost-based rule. Among the reasons for this thesis, McGee gave the difficult assessment and actual irrelevance of the price cutter's intent and the rivals' mental states, on the one side, and the empirical impossibility to distinguish between short- and long-run profit maximization, on the other. ${ }^{71}$ Two reasons that clearly addressed, and countered, the building blocks

${ }^{67}$ Posner, 127 U Pa L Rev at 939 (cited in note 40).

${ }^{68}$ Bork, The Antitrust Paradox (cited at note 11). For Scherer's proposal, see above, Section 3.1.

${ }^{69}$ Bork, The Antitrust Paradox at 155 (cited at note 11).

${ }^{70}$ McGee, 23 (2) J L \& Econ, 292 (cited in note 41). McGee's words will be reproduced almost verbatim in 1986 by the Supreme Court in its famous Matsushita dictum ". . . predatory pricing schemes are rarely tried, and even more rarely successful." See below, Section 7.

${ }^{71}$ Id at 292. 
of those "increasingly complex and speculative models" of predation endowed with strategic and intertemporal features. ${ }^{72}$

Bork's critiques were echoed by Easterbrook. ${ }^{73}$ In one of the earliest papers in the Chicago tradition to acknowledge the pending game-theoretic revolution in IO, Easterbrook devoted two long sections to "Signaling from one market to another" and "Strategic commitments. ${ }^{174}$ In the former he dealt with the argument that a firm may aim at building a reputation of ruthless predator in order to persuade rivals to stay out of, or abandon, its markets. The analysis was not explicitly game-theoretic, but a few hints illuminated the reader about what would soon come about in IO. For example, Easterbrook offered the gist of Reinherdt Selten's chain store paradox, namely, that under perfect information no predation will ever occur (see next Section), yet without quoting Selten's seminal paper. ${ }^{75}$ In any case, his conclusion about signaling and reputation models (see again next Section) was trenchant: "it has not been proved that predatory signaling is a profitable strategy. [. . .] the inconclusive arguments about signaling are inadequate to justify legal intervention." 76 A similar skepticism pervaded the following section of Easterbrook's survey, dedicated to "Strategic commitments", in particular Michael Spence's model of entry-deterring investment ${ }^{77}$ and Williamson's output rule. According to Easterbrook, entry deterrence theories of PP were basically flawed, so much so that "[a]ny attempt to condemn capacity selection decisions as predatory carries with it an unavoidable risk of deterring firms from selecting the most desirable response to change."178 Among the papers he quoted featured one by P. Milgrim (sic!) and

${ }^{72}$ A more explicit critique against the entry deterrence view of PP is at pp. 298-300 of McGee's 1980 article. McGee, 23(2) J Law \& Econ at 298-300 (cited in note 41).

${ }^{73}$ Easterbrook, 48 (2) Univ of Chicago L Rev at 263-337 (cited in note 12).

${ }^{74}$ Id at $282 \&$ accompanying fns.

${ }^{75}$ Id at 285-286. What Easterbrook did refer to was a 1980 NBER paper by R. Masson and R. Roberts (sic! The real co-author was Robert Reynolds) which however was never published, following rejection from the Rand Journal of Economics (Robert Masson, personal communication, April 21, 2009). As a testimony to the new game-theoretic fashion in 1980s IO, that very work eventually led to a publication in the 1985 Journal of Industrial Economics, but only after the addition of a third coauthor (David Easley) and the injection of a new formal argument based on Harsanyi's games of incomplete information (instead of the rational expectations approach used in 1980). The published paper is D Easley, R T Masson and R J Reynolds, Preying for Time, 33 J Industrial Econ 445-460, (1985), one of the most quoted contributions to the game-theoretic literature on $\mathrm{PP}$.

${ }^{76}$ Easterbrook, 48 (2) Univ of Chicago L Rev at 288 (cited in note 12).

${ }_{77}$ A M Spence, 8 Bell J Econ (cited in note 63).

${ }^{78}$ Easterbrook, 48 (2) Univ of Chicago L Rev at 290 (cited in note 12). 
J. Roberts, titled "Equilibrium limit pricing doesn't limit entry," that is to say, the early version of the enormously influential 1982 article by Paul Milgrom and John Roberts that, as I argue below, officially launched the modern game-theoretic approach to PP. ${ }^{79}$ Clearly un-persuaded by the alleged theoretical progress brought by strategic analysis, Easterbrook found no reason to renege on his ironic statement that predation theories were so variegated "for the same reason that 600 years ago there were a thousand positions on what dragons looked like." ${ }^{\prime \prime 0}$

In conclusion, the main element of novelty emerging from the heated post-ATR debate was brought by neither the plea for a comeback to fully-fledged rule of reason scrutiny, nor the search for more refined cost-based or quantity-based rules. Regardless of their beliefs in the frequency and seriousness of PP as an antitrust offense, all of the authors either built, or at least made use of, predation stories that contained explicit intertemporal and strategic features. Static, non-strategic analysis - of the kind underlying the old legal approach to PP cases or Areeda and Turner's paper-seemed completely inadequate in dealing with predation. At the same time, these stories showed that the Chicago mantra of PP as "rarely tried and even more rarely successful" had to be qualified, if not wholly discarded, in view of plausible narratives showing that predation could actually be rational business behavior. Even those authors who abided by Areeda and Turner's operational imperative and who synthesized their contribution in terms of a court-friendly rule had to recognize that the call for new rules stemmed from the inadequacy of the ATR to discriminate among price cuts in a strategic and intertemporal environment. And even those others who stuck to the Chicago mantra could not avoid dealing with the new and richer stories of PP if they wished to uphold their derogatory thesis.

3.5 What was the outcome of the post-ATR debate in US antitrust courts? As with the original Areeda and Turner's article, the impact was quick and relevant. Out of 249 significant $^{81}$ PP cases in the period between 1975 and 1992, at least 18 quoted Scherer 1976 (the first in 1977), 18 referred to Williamson 1977 (first hit in 1978), 6 to Baumol 1979, and 10 to Joskow and Klevorick 1979 (Source: Lexis). In terms of actual law enforcement, absent a new Supreme Court pronouncement on the issue, most courts endorsed a kind of

\footnotetext{
79 P Milgrom and J Roberts, Limit Pricing and Entry Under Incomplete Information: An Equilibrium Analysis, 50 Econometrica 443-459 (1982).

${ }^{80}$ Easterbrook, 48 (2) Univ of Chicago L Rev at 264 (cited in note 12).

${ }^{81}$ On the meaning of "significant" in this context see note 36.
} 
"augmented ATR", 82 which amounted to considering surely lawful a price above average total cost and surely unlawful a price below average variable cost, while considering presumably lawful-a presumption rebuttable by evidence of intent and market structure-a price between AVC and ATC.

The "augmented ATR", which recalled the solution suggested by Joskow and Klevorick ${ }^{83}$ and Brodley and Hay, ${ }^{84}$ brought to an "enforcement equilibrium" in that, far from the populist excesses of the pre-ATR era, plaintiffs enjoyed for a decade or so a low but nonnegligible success rate in PP cases: about 17\% between 1982 and 1993, up from almost nil in the years immediately after the ATR. ${ }^{85}$ Adding the out-of-trial settlements, this is a number that might well represent a balanced approach to the violation. The equilibrium was broken only in 1993, with the Supreme Court's Brooke decision that caused the success rate in PP litigations to drop once more to $0 \%$, leading to a new era of de facto legalization of any price cut by a dominant firm-an era that continues to the present. ${ }^{86}$

Leaving to Sections 6-7 my assessment of Brooke, two remarks may be appropriate here. First, US antitrust courts seemed to be receptive to the kind of PP stories told in the post-ATR literature, but only as long as these stories were translated into an operational cost-based rule like the "augmented-ATR". In other words, rather than being persuaded by the intertemporal and strategic arguments underlying the new stories, courts were attracted by the higher flexibility of the new rules with respect to the strict yes-or-no character of the original ATR. This confirms that at least some of the economists involved in the debate had apparently learned Areeda and Turner's lesson on how to have an impact on the courts-i.e., by offering simple and highly operational rules.

The second remark is that, theoretically speaking, the "enforcement equilibrium" should have shifted in the opposite direction. As I stated previously, the year 1982 marked the official beginning of the new game-theoretic approach to PP. In the following decades that approach has produced several rigorous demonstrations that, far from being irrational, predatory behavior may well be the most profitable choice for a dominant firm in a variety of plausible settings-in other words, that many convincing stories may be told in the courts to demonstrate that PP is an actual possibility. More-

\footnotetext{
${ }^{82}$ Bolton et al, 88 Georgetown L J 2253 (cited in note 23) (this article named it).

${ }^{83}$ Joskow and Klevorick, 89(2) Yale L J at 245 and fns (cited in note 40).

${ }^{84}$ Brodley and Hay, 66 Cornell L Rev at 738-803 (cited in note 8).

${ }^{85}$ Bolton et al, 88 Georgetown L J 2254 (cited in note 23).

${ }^{86}$ Brooke Group Ltd. v Brown «) Williamson Tobacco Corp, 509 US 209 (1993).
} 
over, one of the key findings has been the irrelevance of relationship between the alleged predatory price and the leader's production costs; this entails that the boundaries of the "augmented ATR" may well be trespassed, as even a price above ATC may still be predatory if properly interpreted in terms of a rigorous strategic story. Thus, one should expect that, as it had happened in 1975, antitrust courts would swiftly embrace the new theories, and accordingly revise their pro-plaintiff record. Yet, the opposite actually happened: Brooke shifted the enforcement equilibrium further from where adherence to the new strategic theories should have led it. At the same time, the gametheoretic approach to predation has been almost totally neglected by US courts

\section{IT'S A BRAND NEW GAME: THE METHODOLOGY OF STRATEGIC PREDATION}

The development of rigorous strategic models for PP in the early 1980s is a landmark in the history of modern game theory. These were among the earliest models where new techniques and solution concepts were applied to analyze the so-called asymmetric information games (AIG henceforth), i.e., games devoid of the traditional assumption of perfect information. It goes well beyond the boundaries of this paper to investigate how and why AIG were developed, as well as their influence on the rise of modern information economics (including mechanism design theory), and on the establishment of game theory as the hard core of neoclassical economics (a result the first generation of game theorists had largely missed). ${ }^{87}$ Suffice it here to say that, thanks to the contributions of Reinherd Selten and John Harsanyi, and the related extension of strategic analysis to games with imperfect or incomplete information, it is hardly an exaggeration to speak of a late 1970s-early 1980s "resurrection" of game theory-a fresh start whose eventual consequences may be best appreciated by comparing the discipline's relevance within economics before and after those crucial years. Indeed, the circumstance that some of the foundational papers of the AIG literature were also the milestone for the strategic approach to PP may somehow make up for a more thorough reconstruction. The gist of the argument supporting the strategic analysis of predation may in fact partly capture the actual motivation behind the overall "resurrection" of game theory.

\footnotetext{
${ }^{87}$ It is a story still awaiting to be fully told, but see N Giocoli, Three Alternative (?) Stories on the Late 20th-Century Rise of Game Theory,14 (2) Studi e Note di Economia, 187-210 (2009).
} 
The crucial role played by Selten in this story makes it hardly surprising that one of those key papers was his classic 1978 contribution, with the celebrated chain store paradox. ${ }^{88}$ In that paper Selten proved that no predation existed in the game equilibrium under perfect information. Yet, from the viewpoint of antitrust law and economics, the real message of Selten's result-and the correct way to interpret it-was the opposite. PP could not be a problem only under the heroic assumption of perfect information, because the assumption was crucial for the logic of backward induction to generate the paradoxical outcome. Thus, the result looked like an invitation to game theorists to investigate what the game equilibrium would be with the addition of a bit of imperfect or incomplete information. And given that PP was the specific instance of economic behavior that Selten had chosen in order to exemplify his analytical result, it was natural for those accepting Selten's invitation to build their new games around predation stories.

Why did Selten choose PP as the theme for his seminal paper? More importantly, ${ }^{89}$ why did predation provide such a fertile ground for the new game-theoretic literature? Part of the answer is that, since the postwar years, IO problems in less-than-perfectly competitive markets have always constituted the most natural setting for game theory. But why PP in particular (i.e., a problem of dominant firm behavior) instead of a more obvious pick, like, say, oligopoly or collusion? The answer lies in what economists had already noticed as the necessary intertemporal and strategic characteristics of predation. The simple notion of "cut price now to earn more profits tomorrow" creates a very friendly environment for AIG modeling because it is a notion which-generally speaking-calls for the formulation of sequential strategies by both the predator and the possible prey, with each of these strategies entailing an account of a firm's knowledge and expectations about the rival's characteristics and behavior. Moreover, several stories already existed to render in plain language the conjectural and behavioral sequences underlying a predation episode. As we know from the previous sections, these were all features of PP that economists had well understood by the late 1970s. What game theorists were required to do was simply to formalize them by either transforming existing PP stories into formal sequences of actions and beliefs or inventing brand new ones. Furthermore, PP offered highbrow game theorists the ideal environment to give actual import to what would otherwise look like purely abstract arguments (think of the new solution concepts for Bayesian

\footnotetext{
${ }^{88}$ R. Selten, The Chain-Store Paradox, 9 Theory \& Decision, 127-59 (1978).

${ }^{89}$ Especially in view of Selten's own answer to the previous question: see id at 158 , fn.1.
} 
games), totally detached from real world problems. In other words, assuming you were a game theorist, still striving in the early 1980s to persuade the wider audience of economics practitioners of the practical relevance of your analytical tools, the problem of predation offered an excellent opportunity to score a few easy points. Indeed, by focusing on the more reasonable case of imperfect or incomplete information, AIG also scored a point in terms of superior realism, if compared with the (often implicit) assumption of perfect information for standard price-theoretic models. ${ }^{90}$

The events following Selten's 1978 result are fairly well known by anybody acquainted with modern IO. In 1982, two pairs of authors, John Milgrom and Paul Roberts, and David Kreps and David Wilson, published a set of papers ${ }^{91}$ that, by applying AIG to the twin problems of limit and predatory pricing, marked the official beginning of the modern game-theoretic approach to antitrust economics-where the italicized word "modern" should be read as synonymous to "à la Harsanyi-Selten", i.e., of games with less than perfect information. After this first inflow, a flood of strategic literature followed. At the end of the 1980s, the entire field of IO had been re-designed in terms of game-theoretic tools, methods and ways of reasoning. One of clearest signs of the success of game theory in conquering IOthereby fulfilling 45 years later the prediction first formulated at the time of von Neumann and Morgenstern's Theory of Games and Economic Behavior ${ }^{92}$ - was the publication in 1989 of the Handbook of Industrial Organization, a magnus opus and fundamental reference where game-theoretic modeling was simply ubiquitous. ${ }^{93}$

\footnotetext{
${ }^{90} \mathrm{I}$ just mention here another possible explanation for the game theorists' choice, namely, an "ideological" willingness to apply the new tools of AIG in order to counter the success (especially in courtrooms) of the Chicago approach to antitrust, of which the new legal attitude towards PP was one of the clearest manifestation. This is for example what may be drawn from Robert Wilson's brief explanation of the motivation behind the AIG literature. R Wilson, Strategic Models of Entry Deterrence, in R Aumann and S Hart, eds, 1 The Handbook of Game Theory, 306 (NorthHolland, Amsterdam 1992). We will examine an explicit effort in this direction below, section 9 .

${ }^{91}$ P Milgrom and J Roberts, 50 Econometrica 443-459 (cited at note 79); P Milgrom and J Roberts, Predation, Reputation and Entry Deterrence, 27 J Econ Theory 280-312 (1982); D Kreps and R Wilson, Reputation and Imperfect Information, 27 J Econ Theory 253-79 (1982).

92 "This work [i.e., AIG] holds some promise of yielding a partial and muchbelated realization of some of the hopes that were expressed in the early years of game theory." P Milgrom and J Roberts, Informational Asymmetries, Strategic Behavior, and Industrial Organization, 77 (2) Am Econ Rev, Papers \& Proceedings 187 (1987).

${ }^{93} \mathrm{R}$ Schmalensee R. and R D Willig, The Handbook of Industrial Organization (North-Holland, Amsterdam 1989).
} 
The common thread in the three foundational papers was that, in a realistic setup of less than perfect information, a firm endowed with market power may try to discourage competitors from entering, or remaining, in the market by manipulating their beliefs. The idea was introduced in Milgrom and Roberts Econometrica paper and applied to limit pricing, but it was soon extended by the same authors, as well as by Kreps and Wilson, to PP. When a firm considers entering a market, it must base its decision on its expectations of post-entry profits. This depends on whether the incumbent responds aggressively and, if so, on the intensity of the aggressive response (say, how much will the price fall following entry?). Hence, the potential entrant's expectations are crucial in determining its own entry decision. But the incumbent can, through its actions, influence these expectations. ${ }^{94}$

While it would be impossible to manipulate a rival's beliefs under the perfect information setup in price-theoretic models, adding a little bit of either asymmetric or incomplete information makes the trick. For example, by responding aggressively to entry, a predator may be able to convince that specific entrant, or any other future entrant, that entry is unprofitable. It follows that predation does not even have to "kill" the competitor in order to achieve its goal of affecting the rivals' expectations and thus be a profitable strategy. In the case of a multi-market incumbent, it is not even necessary that the predator directly profits from its price-cutting in the contested market. Moreover, contrary to McGee's 1958 results (which Milgrom and Roberts wrongly took as the state-of-the-art on in PP literature),$^{95}$ if the incumbent does succeed to drive a competitor out of the market, new entry will not inevitably follow as soon as the incumbent raises its price to reap the benefits of its success because it is now possible that other potential entrants-having witnessed the poor lot of their predecessor-will no longer expect entry to be profitable.

Assessing their achievement in a 1987 paper, ${ }^{96}$ Milgrom and Roberts identified PP as the best example of the theoretical gains pro-

${ }^{94}$ P Milgrom, Predatory Pricing, in: J Eatwell, M Milgate and P Newman (eds.), The New Palgrave. A Dictionary of Economics (MacMillan, London 1988).

${ }^{95} \mathrm{P}$ Milgrom and J Roberts, Informational Asymmetries, Strategic Behavior, and Industrial Organization, 77 (2) Am Econ Rev, Papers and Proceedings 184-193 at 185 (1987). This position was only partially corrected in a later paper, where they still failed to mention the strategic-oriented post-ATR literature. P Milgrom and J Roberts, New Theories of Predatory Pricing, in G Bonanno and D Brandolini (eds.), Industrial Structure in the New Industrial Economics 112-137 (Oxford 1990).

${ }^{96}$ Milgrom and Roberts, 77 (2) Am Econ Rev (cited at note 95) 
vided by the AIG perspective. Totally neglecting the outcomes of the post-ATR debates, and in clear reference to the most extreme Chicago position, they claimed that, circa 1980, the only consistent analysis of PP, based as it was on the compelling logic of standard price theory, indicated that predation could not be expected to succeed and was not a rational strategy. Notwithstanding real world instances of PP by dominant firms, mainstream economists were unshaken: "because no mere fact ever was a match in economics for a consistent theory, these ideas began to represent the basis for a new consensus." 97 Yet, they continued, this consensus decisively rested on the implicit assumption of symmetric information. It was precisely here that their contribution had brought a crucial improvement, first and foremost in terms of the realism of the model's conclusions. AIG showed that predation could well be rational under more realistic informational settings, so much so that we should expect to see predatory strategies being undertaken by real world firms, unless effectively deterred by legal prohibitions. Milgrom and Roberts proudly concluded that in a few years the AIG methodology had allowed the first truly satisfactory treatment of a vexed issue like PP. This was a general result: the kind of business behavior emerging from AIG's equilibria captured a lot more of the richness of observed reality. ${ }^{98}$

One last crucial innovation brought by AIG to PP literature is the dismissal of cost considerations as the essential tool for demonstrating actual predation. Game-theoretic models undermine the ATR and all its variants because AIG not only shows that predation can be profitable, but also that predatory prices "bear no necessary relation" to the incumbent's marginal or average costs. ${ }^{99}$ This is the logical consequence of the fact that predation aims at affecting the rivals' expectations of future profits. Why should such an effect depend on the incumbent's production costs? At most, it should depend on the entrant's costs-and possibly on none's costs at all. As a confirmation, the PP stories emerging from the AIG literature hardly make any reference to production costs. It is to these stories that we now turn.

\section{AND A NEW PLAYBOOK TOO!}

Among the early 1980s game-theoretic models featured a rigorous formulation of the traditional deep-pocket version of $\mathrm{PP}$, frequently

\footnotetext{
${ }^{97}$ Id at 185 .

${ }^{98} \mathrm{Id}$ at 187 . On superior realism, rather than higher rigor, being the true plus of AIG, also see L Phlips, The Economics of Imperfect Information, ch 7 (Cambridge 1988).

${ }_{99}$ P Milgrom and J Roberts, New Theories of Predatory Pricing at 115 /cited in note 95$)$.
} 
referred to in the legal realm (see above, section 1). In a 1984 paper Jean-Pierre Benoit showed that even that story, effectively demolished by McGee in 1958, could nonetheless be rescued and given a solid theoretical basis if some asymmetric information (e.g. about the depth of a firm's pocket) was added to the model.

Assume the entrant is financially constrained as in the classic legal story. If the incumbent is uncertain about the entrant's willingness to fight predation until bankruptcy, then PP episodes may actually happen. In other words, under less-than-perfect information a predatory price war-aimed at the "usual goal" of driving the entrant out of the market (not at deterring other potential entrants, like in most AIG models) and ending up with either cooperation or the entrant's defeat-may obtain as an equilibrium phenomenon. ${ }^{100}$ Thus, as long argued in legal literature, it may sometimes be rational for a firm that is financially stronger than another to use its deeper pockets to set a low price and force its rival out of the market. Note that this is the only instance of an AIG-based story where below-cost pricing is essential for predation, though even here price need not be below the predator's marginal or average cost as in ATR. What is needed is that price be set so low that it generates a negative cash flow for the prey. Hence, it is the prey's costs that matter, not the predator's. ${ }^{101}$

Apart from Benoit's model, the new AIG playbook of PP only contained stories where predation was used to manipulate the other firms' beliefs. Three basic plots were offered in this literature. In the first, so-called signaling models, ${ }^{102}$ the incumbent has an informational advantage about a market feature which is key to the prey's exit and output decisions-for example his own (i.e., the incumbent's) production costs. The prey may infer the rival's costs by observing his pricing behavior, but this is exactly where the possibility arises for the incumbent to bias the rival's inferences by setting a predatory price in order to look like a "tough" (i.e., low-cost) competitor. However, at the equilibrium of the signaling game (a rational expectation equilibrium) PP does not induce the prey to either underestimate the profitability of continuing operation or overestimate the predator's toughness. It follows that, according to Milgrom and Roberts's story, predation does not cause the prey's exit nor restrains its future price and output choices because it fails to affect its beliefs. Why

${ }^{100} \mathrm{~J}$ P Benoit, Financially Constrained Entry in a Game with Incomplete Information, 15 (4) R and J Econ, 15 490-499 (1984).

${ }^{101}$ It must be added that Benoit's model is the weakest, theoretically speaking, among those of the first AIG generation. For a critique see Milgrom and J Roberts, New Theories of Predatory Pricing 120 (cited in note 95); M Motta, Competition Policy: Theory and Practice, 435 (Cambridge 2004).

${ }^{102}$ P Milgrom and J Roberts, 50 Econometrica 443-459 (cited at note 79). 
then should the incumbent be willing to undertake PP if it is not going to succeed? The answer provided by Milgrom and Roberts is a perfect example of the game-theoretic logic: the prey is so rational that it is perfectly capable of understanding the incumbent's incentives, so much so that were the latter not to prey, the former would conclusively infer that he is a "soft" (i.e., high-cost) competitor and thus would compete more aggressively against him.

A second category of AIG-based PP story is that of so-called signaljamming models. ${ }^{103}$ The typical setting is that of test-marketing predation. Assume the prey is running a marketing test for a product to be launched in a market where the predator is already active. The incumbent may then try to disrupt the prey's test by secretly lowering his price (say, by offering discounts to his distributors or loyal customers) or by undertaking any other action that may lead the prey to misread the test's results and underestimate the profitability of entry in that market. As in signaling models, predatory behavior has no effect on the prey's equilibrium choice; once again, the predator fails to exclude or discipline the rival. Yet, preying is still mandatory for him, given the prey's rational expectation that he will do it. As before, this fact may itself deter some entry, thus raising antitrust concerns.

The third kind of story is perhaps the most well known and has to do with the incumbent's reputation, as in Milgrom and Roberts' and Kreps and Wilson's. ${ }^{104}$ The incumbent's goal is explicitly to deter future entry by preying on current rivals, regardless of whether his behavior actually induces the target to exit the market. The informational asymmetry here is that it is private information to the predator whether he would undertake PP in a specific market. The fact that the "willingness to prey" is private information means that, from the prey's viewpoint, there is a positive probability that the incumbent is a "natural predator", i.e., a firm always preying upon his rivals. As a consequence, failure to prey once would destroy any reputation of being a natural predator forever, leading to future entry of all possible rivals. It follows that preying may be worthwhile for the incumbent even if it is immediately costly, since fighting entry today is the only way to preserve an incumbent's reputation and thus deter any entry tomorrow. The natural setting for these reputation models is that of multi-market firms, where what happens in one market is observable by actual and potential rivals in another

${ }^{103}$ D Fudenberg and J Tirole, A 'Signal-Jamming' Theory of Predation, 17 RAND J Econ 366-377 (1986).

${ }^{104}$ P Milgrom and J Roberts, 27 J Econ Theory (cited at note 91); Kreps and Wilson, 27 Econ Theory (cited at note 91). 
market. The more the markets, the greater the incentive to preserve reputation by always fighting entry. AIG reputation models thus suggest that predation is a real possibility. The lack of complete information can lead to an equilibrium where not only entry is deterred by predation, but predation actually must occur. ${ }^{105}$

Preying-for-reputation, much like preying-for-signaling or preyingfor-jamming, is a pole apart from the yes-or-no character of straight tests, like the ATR. Every behavior aimed at affecting a rival's beliefs may vary quite a lot in breadth and intensity, but this makes much harder for antitrust enforcers to detect it. Moreover, the fact that the welfare costs of PP are said to come more from dynamic inefficiency (deterrence of entry, which means undesirable obstacles to new investments and new products) than from static one (straightforward deadweight loss due to post-predation monopolization) makes the whole story much more debatable and the costs themselves extremely difficult to assess, if not purely virtual.

To summarize, in the first half of the 1980s, a strong theoretical argument was developed showing that it was simply bad economics to argue that PP was necessarily irrational. Hence predatory behavior did deserve the attention of antitrust law, as it might well be a real world phenomenon. Though the argument was purely theoretical, it was marketed in terms of a bouquet of plausible stories (signaling, jamming, and, above all, reputation-building) which could be verified against the facts of actual antitrust cases. What courts were ideally called in to do was to look for supporting evidence for one of these stories and, for the rest, trust game theory as far as the necessary relationship between the story itself and the predatory nature of the firm's behavior were concerned. Above all, no costs had to be estimated and no bright-line rule could be applied. Contrary to Areeda and Turner's operational urge, game theory showed that dealing with PP cases necessarily required that courts undertake the painstaking work of disentangling the litigation facts in order to bring to the surface the outline of one or the other of the AIG stories.

\section{THE AIG PLAYBOOK IN COURTS}

It is remarkable for our narrative that the first critiques against the AIG methodology came from two of the authors who had contributed to its development. In their 1987 paper Milgrom and Roberts listes several issues that should be carefully assessed before applying 98).

${ }^{105}$ See Phlips, The Economics of Imperfect of Information at 217-18 (cited at note 
their own models' prescriptions to law enforcement. ${ }^{106}$ First in their list are the stronger rationality requirements. Milgrom and Roberts admit that AIG agents are much more sophisticated in their inferences, calculations and forecasts than in the price-theoretic world of competitive markets with given equilibrium prices. While it is obvious that the rationality standard goes up as soon as we distance ourselves from the world of perfect information, still what they call "a quantum leap" is entailed by the kind of rationality required for AIG. This amounts to the ability to fully anticipate the other players' complex responses, including the fact that those responses "depend on subtle inferences that competitors draw, often by very intricate reasoning, from their conjectures about others' behavior and their observations." 107 In short, agents in AIG models are called to solve more difficult decision problems than their counterparts in price-theoretic settings. This in turn makes the equilibrium assumption more implausible. Moreover, it is natural to conclude that "the descriptive accuracy of the super-rationality assumption does seem minimal." 108

Secondly, and of utmost importance in our narrative, comes the dubious robustness of AIG results. Milgrom and Roberts underline "the apparent sensitivity of the results to alterations in what one might think is [the] fine structure of the models."109 Indeed, the game-theoretic literature demonstrates that introducing just "a tiny bit of private information into such a model can radically change its equilibrium outcomes"110 In a sense, the AIG technique is too powerful since by introducing the "right" amount of information asymmetry, one can show that "almost anything can be made an equilibrium."111 This result, formally proved by Drew Fudenberg and Eric Maskin, belongs to the class of Folk Theorems and has ominous consequences in terms of the practical applicability of AIG models in antitrust courts. ${ }^{112}$

To give a hint as to what this entails (see Section 10 for further discussion), the result may be interpreted as indicating that PP is just one of the infinite possible equilibrium outcomes of a given strategic situation, namely, the one emerging when firms are credited with a very specific set of beliefs descending from a very specific kind of informational imperfection-precisely that set and that imperfec-

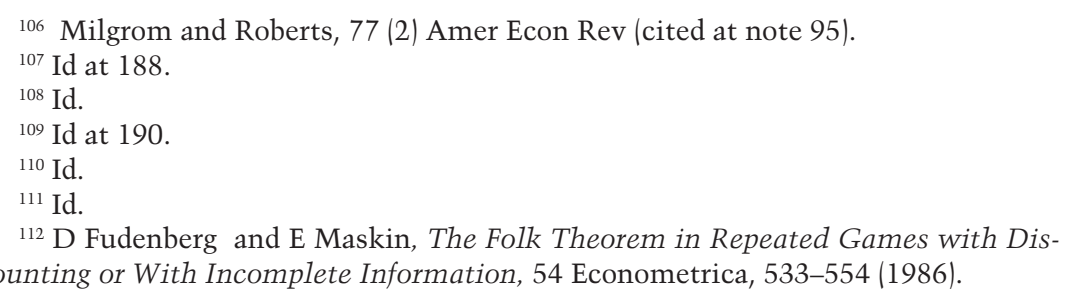


tion out of an infinite array of possibilities. Borrowing from Milgrom and Roberts, one could then legitimately ask which of the infinite possibilities of informational asymmetry have "survival value", i.e., correspond to a situation (technically a distribution of the predator's types) to which competing firms ascribe a positive probability. Or, more succinctly, one could wonder whether AIG stories are really plausible or just conceptually possible. ${ }^{113}$

Before digging more deeply into such a crucial issue, let's go back to Milgrom and Roberts for a further questionable feature of AIG, when viewed as a tool for antitrust law-making. The models analyzed in Section 5 show the possible rationality of a behavior that is predatory in both intent and form, though not exactly the type of conduct traditionally termed "predatory" as it entails no necessary relationship between a firm's price and its production costs. Should this new species of predatory behavior be a concern for antitrust law? As stated before, strategic predation can be socially costly because of its deterrence of future entry, even if it fails to eliminate current rivals. Hence, Milgrom and Roberts concede that it would be good to prohibit it, if it could be correctly identified. ${ }^{114}$ The problem is that in order to identify it, we should be able to recognize what is a firm's "right" price, where "right" means, in the AIG context, the price that the firm would charge if the market and informational conditions were such as to exclude any possibility to affect the rivals' behavior or beliefs. Determining such a price is, as Milgrom and Roberts admit, a mind-boggling problem. Hence, their surprising conclusion:115 "Doing so would surely cost more than any efficiency gain one might realize from reducing the height of deadweight-loss triangles. [. . . If so, it may be best simply to give up on

${ }^{113}$ For economic models as merely "possible worlds." see S Rappaport, Models and Reality in Economics ch 7 (Elgar 1998). It must be added that a few advances on the empirical validation of AIG models of PP have been made since then. B H Kobayashi, The Law and Economics of Predatory Pricing, in K N Hylton, ed, Antitrust Law and Economics, Ch.6. (Edward Elgar, Cheltenham 2010); surveys this empirical literature, arguing that some evidence-either econometric (as in, say, Burns or Scott Morton) or direct (as in, say, Zerbe and Munford or Genesove and Mullin)-has been found in favor of the new stories, especially reputation ones. M R Burns, Predatory Pricing and the Acquisition Cost of Competitors, 94(2) J Pol Econ 266-296 (1986); F. Scott Morton, Entry and Predation: British Shipping Cartels 1879-1929, 6 (4) J Econ ↔) Management Strategy 679-724 (1997); R O Zerbe and M T Mumford, Does Predatory Pricing Exist? Economic Theory and the Courts After Brooke Group, 41 (Winter) Antitrust Bulletin 949-985 (1996); D Genesove and W P Mullin, Predation and its Rate of Return: The Sugar Industry, 1887-1914," 37 (1) RAND J Econ 47-69 (2006).

${ }^{114} \mathrm{P}$ Milgrom and J Roberts, New Theories of Predatory Pricing at 133 (cited in note 95$)$.

${ }^{115}$ All the more surprising if we think that AIG results are usually interpreted as conducive to a stricter enforcement of anti-PP prescriptions. See Motta, Competition Policy at Ch 7 (cited in note 101). 
attempts to control predation, even if one believes that it can and does occur."116

Let me summarize this argument as follows. The whole point of AIG is to show that PP may indeed be rational, but since PP bears no relation to costs (and thus to cost rules), it is impossible to identify it objectively and cheaply, therefore it is better to ignore it as an antitrust violation. In short, game-theoretic models demonstrate that the only kind of rational predation is one no antitrust court or authority will ever be able to detect.

The same paradoxical conclusion may be reached if we consider how another early supporter of AIG, industrial economist Louis Phlips, describes the procedure through which a court should detect $\mathrm{PP}$ behavior in actual antitrust cases. The only way a court may achieve a sufficient degree of certainty about a predation violation is by collecting evidence related to one of the AIG stories. The evidence need not be about whether the prey was forced out of the market or whether its cash flow remained positive. What should be proved, by either the plaintiff or the court, is that the alleged predation turned a profitable entry opportunity into an unprofitable one. This, notes Phlips, amounts to showing that, absent the incumbent's price cut, there was room in the market's normal competitive equilibrium for an additional firm, and that, as a result of the cut, the market price went below the noncooperative (i.e., Nash) equilibrium level. ${ }^{117}$

The point is that such a proof is extremely difficult to provide in practice. Firstly, because AIG show that predation may occur only when there is sufficient uncertainty about the low price being the outcome of either normal competition or predatory behavior. Secondly, because the theoretical yardstick for discussing whether the market has enough room for an additional firm, is the post-entry competitive equilibrium, with its implied price and market shares. But how may a court effectively compute this equilibrium given the necessarily incomplete information about cost and/or demand? Phlips argues that real world firms are always capable of computing their own market's Nash equilibrium, as this is the "natural outcome" of imperfect competition under incomplete information. It follows that both the incumbent and the entrant should be able to say what the post-entry competitive price and market shares would have been in case of entry and no predation. The court should then simply discover this information and use it as the yardstick to evaluate the actual market performance.

${ }^{116}$ P Milgrom and J Roberts, New Theories of Predatory Pricing at 134 (cited in note 95).

${ }^{117}$ Phlips, The Economics of Imperfect of Information at 240-41 (cited at note 98). 
This argument might be easily rejected by playing an Austrian tune and recalling that the main reason why our societies rely on (and defend) competition is precisely because nobody can calculate what the equilibrium prices would be in its absence. ${ }^{118}$ But the real counter-argument to Phlips is simpler than that. Leaving aside the firms' actual ability to compute it, it is sufficient to recognize that no court or judge would ever buy the idea that an esoteric concept like Bayesian-Nash equilibrium ${ }^{119}$ would be the "natural outcome" of less-than-perfectly competitive markets; this for the very simple reason that the rationality requirements behind this and similar solution concepts are far too strong to be taken seriously in any real life situation. Thus, the complexity of game-theoretic models makes them unattractive to antitrust courts and judges eager for simple rules and worried about the risk of committing too many Type I errors, i.e., wrong condemnations of innocent, pro-competitive price cuts. ${ }^{120}$ Indeed, most Nash equilibrium refinements are, at best, just normative notions showing how ideal players, potentially capable of deploying the full power of their rationality, should behave (and reason) in specific strategic situations. They are, in the words of leading game-theoretician Ariel Rubinstein, just fables. ${ }^{121}$ But if the kind of game theory behind AIG is just prescriptive, how could a given court or judge ever apply it when deciding a concrete antitrust case?

That this has been the attitude in US antitrust courts may be easily demonstrated by looking at trial databases. According to Lexis, of the hundreds of federal cases dealing with PP indictments through the year 2000, ${ }^{122}$ none ever mentioned Milgrom and Roberts or Kreps

${ }^{118}$ H Demsetz, How Many Cheers for Antitrust's 100 Years?, 30 (2) Economic Inquiry 207-217 at 215 (1992).

119 A Bayesian Nash equilibrium is defined as a strategy profile and set of beliefs specified for each player about the types of the other players that maximize the expected payoff for each player given their beliefs about the other players' types and given the strategies played by the other players. It is a solution concept that naturally yields a multiplicity of equilibria in dynamic games if no further restrictions are placed on the players' beliefs. As already stated, the problem of multiplicity only makes things worse in terms of the notion's concrete applicability.

${ }^{120}$ F S McChesney, Talking 'Bout my Antitrust Generation, 27 (3) Regulation 48-55 (2004).

${ }_{121}$ "As economic theorists, we organize our thoughts using what we call models. The word "model" sounds more scientific than "fable" or "fairy tale" although I do not see much difference between them." A Rubinstein, Dilemmas of an Economic Theorist, 74 (4) Econometrica 881(2006).

${ }^{122}$ If we consider only the cases where the words "predatory" or "predation" feature in either the case overview or core terms, there are more than 440 cases in the time span 1975-2000 and more than 260 from 1990 to 2000. 
and Wilson or Benoit or Fudenberg and Tirole, or even Ordover and Saloner 1989's survey on the game-theoretic approach to monopolization and antitrust. ${ }^{123}$ And even turning to the predation stories underlying AIG, what we find is just a handful of references (four or five overall) to either reputation or signaling. Recalling the immediately huge impact of Areeda and Turner's 1975 paper and its followups (see above, Section 3), we may conclude that, in terms of actual influence on the way US courts handle PP cases, AIG has been an almost complete fiasco.

\section{GAME OVER: BROOKE AND THE TRIUMPH OF THE CHICAGO SCHOOL}

In the previous Sections we have explained how things radically (and quickly) changed in both the doctrinal environment and the lower courts' attitude after the publication of Areeda and Turner's 1975 article. It is now time to complete our story, by illustrating when and how the transformation reached the Supreme Court. The first application by the Supreme Court of the ideas emerging from the debate on the various price/cost rules came in 1986, with the Matsushita decision. ${ }^{124}$ There, the Court endorsed the principle that a charge of predatory behavior had to be supported by evidence on the relationship between the defendant's price and cost, along the lines of the post-ATR literature. Moreover, as a second requirement, the plaintiff had to show if and how the predator, after excluding its rival(s), could make up for the sacrifice of short-term profits suffered during the period of below-cost pricing-the so-called recoupment test, which a few years later became the hallmark of another crucial decision, Brooke. ${ }^{125}$

In the latter case, the Court did something unprecedented in antitrust cases, that is to say, it set aside a jury verdict based on a review of the sufficiency of the evidence, and explicitly declared that plain-

${ }^{123} \mathrm{~J}$ A Ordover and G Saloner, Predation, Monopolization and Antitrust, in R Schmalensee and R D Willig, The Handbook of Industrial Economics at 537-596 (North-Holland, Amsterdam 1989).

${ }^{124}$ Matsushita Elec Indus Co v Zenith Radio Corp, 475 US 574 (1986).

${ }^{125}$ Brooke Group Ltd v Brown «) Williamson Tobacco Corp, 509 US 209 (1993). Glazer downplays the novelty of the recoupment test in Brooke, saying that after Matsushita the requirement was "yesterday's news", so much so that the Brooke plaintiff (that Glazer himself represented during all stages of the litigation) easily accepted the need to prove recoupment-and even succeeded at that. K L Glazer, Predatory Pricing and Beyond: Life after Brooke Group, 62 Antitrust L J 605-633 fn 13 (1994). 
tiffs in a PP case must not only show that the defendant has a genuine possibility of preying upon the rival, by either forcing its exit or disciplining it, but also that the defendant has a strong prospect of recouping the losses suffered during predation. ${ }^{126}$ Specifically, the Brooke Court stated that, firstly, PP requires proof of below-cost pricing (though no specific cost rule was referred to) ${ }^{127}$ and, secondly, that PP requires proof of recoupment. Hence, below-cost pricing is just a necessary, but not a sufficient condition for monopolization. In order to satisfy the second requirement, plaintiffs must not only prove that below-cost pricing either excludes or disciplines the prey, but also that the predator will afterwards be able to raise the price above the competitive level and that this will compensate him for the losses during the predatory phase.

The recoupment test itself entails two different elements of proof. The plaintiff must demonstrate not only that the successful predator has been, or will be, able to raise price above the competitive level (so-called recoupment capability), but also that the increase has been, or will be, sufficient to compensate the predator for its predatory losses (so-called recoupment sufficiency). Moreover, in order to prove the actual, or prospective, profitability of predation, plaintiffs are required to demonstrate as a necessary precondition that the market structure is such as to potentially allow recoupment in the first place-something that in turn calls for, at the very least, a proof of structural features such as market concentration, existence of entry barriers and the predator's capacity to absorb the prey's market share. ${ }^{128}$ The accusation will be summarily dismissed absent the demonstration of the proper structural conditions, or of any other of the various prongs of what, after 1993, has been called the Brooke test. Far from being inconsistent with, or in opposition to, the ATR and its variants, the recoupment test has actually provided defendants in PP cases with a second, alternative weapon. After 1993 a defendant can prevail in summary judgment by winning in either the recoupment or the price-cost section of the Brooke test. ${ }^{129}$

\footnotetext{
${ }^{126}$ More precisely, that a "dangerous probability" of recoupment exists if the case is a Sherman Act $\S 2$ violation, while a "reasonable prospect" of recoupment is required if the case is a Robinson-Patman Act, anti-price discrimination violation. Matsushita was an instance of the former, Brooke of the latter.

${ }^{127}$ It was just required that price be below "some measure of incremental cost." Brooke, 509 US at 223.

${ }^{128}$ Bolton et al, 88 Georgetown L J at 2255-56 (cited in note 23).

${ }^{129}$ Hovenkamp, 41 Antitrust Bulletin at 833 (cited at note 46). The fact itself of applying summary judgment to an antitrust case-a solution explicitly disfavored by
} 
What makes Brooke so important for our story is that it was the first time since the ATR "revolution" that the Court made its own views about PP fully explicit. These consisted of a strong skepticism about the robustness of predation claims, and a true sea-change from the Court's earlier idea of competition as such a fragile process that it had to be protected from any significant price reduction made by big firms. ${ }^{130}$ Indeed, the Brooke Court went much farther than the simple endorsement of either the ATR or one of its variants. ${ }^{131}$ Not even the observation of below-cost pricing, combined with the theoretical possibility of recouping (which, as we know, is by itself quite unlikely), should be considered sufficient to validate an accusation of predatory behavior absent convincing truth proof of the actual likelihood of sustained supra-competitive pricing and recoupment. Hence, as noted by Kobayashi ${ }^{132}$, the idea was explicitly rejected that the mere theoretical possibility of welfare harm could provide a basis for antitrust liability. The Court noted that, although the plaintiff's economic expert had presented a theory of predatory price discrimination $^{133}$ and had affirmed his belief that, according to that theory, a reasonable possibility existed that the defendant's behavior might have injured competition, "this does not alter our analysis. When an expert opinion is not supported by sufficient facts to validate it in the eyes of the law, or when indisputable record facts contradict

the Supreme Court in Poller v CBS, 368 US 467, 473 (1962), heralded a sea-change in jurisprudential attitude towards antitrust violations. See Hovenkamp, 41 Antitrust Bulletin at 822 (cited at note 46). Even the much-debated Twombly decision by the 2007 Supreme Court (on which see below, Section 8.2) may be considered as a further step in this direction. Richard Epstein speaks of Twombly as establishing "summary judgment in disguise." R A Epstein, Of Pleading and Discovery: Reflections on Twombly and Iqbal with Special Reference to Antitrust, 2011 (1) U Ill L Rev187-213 (2011).

${ }^{130}$ D J Boudreaux, K G Elzinga and D E Mills, The Supreme Court's Predation Odyssey: From Fruit Pies to Cigarettes, 4 S Ct Econ Rev 57-93 at 72. Glazer notes that the Brooke plaintiff's case was very strong, so much so that the decision, as well as the Court's willingness to take a procedurally unusual step, says a lot about the latter's general attitude towards PP. K L Glazer, 62 Antitrust L J at 606 (cited at note 125 .

${ }^{131}$ Though Areeda and Turner themselves had briefly mentioned the recoupment test in their paper: "predatory pricing would make little economic sense to a potential predator unless he had [. . . ] a very substantial prospect that the losses he incurs in the predatory campaign will be exceeded by the profits to be earned after his rivals have been destroyed." Areeda and Turner, 88(4) Harv L Rev at 698 (cited in note 1) (1975 article).

${ }^{132}$ Kobayashi, Law and Economics of Predatory Pricing (cited in note 113).

${ }^{133}$ Recall that Brooke was a Robinson-Patman case. See note 125. 
or otherwise render the opinion unreasonable, it cannot support a jury's verdict." 134

As we already know, the most visible outcome of Brooke has been that, after 1993, no plaintiff has won a PP case at federal court level: a 0\% condemnation rate in 39 PP federal cases from 1993 to 2000. It is not hard to see why. As noted by Bolton et al. ${ }^{135}$, the combination of the exacting standard of proof set by the Brooke Court, plus the theoretical skepticism that PP could be a plausible business strategy, plus the judicial neglect of modern strategic theories of PP (of the kind analyzed in the previous Sections), easily explains the plaintiffs' miserable success rate after 1993-which in turn validated Glazer's dismal prophecy for the future of PP as an antitrust violation. ${ }^{136}$ In short, after Brooke price cuts made by dominant firms have once again become de facto legal in the US, as had previously happened immediately after the ATR.

But where did the Brooke test come from? What brought the 1993 Court to completely reverse its 1960s attitude? In particular, given that the role of the recoupment test is precisely to warrant that no PP accusation may end up deterring competitive behavior, ${ }^{137}$ where did the Court take the very idea that some competitive practices may exist which, though potentially harmful, could not be condemned without causing more damage to other, surely pro-competitive conducts?

The obvious answer is that this view, first developed by the Court in Matsushita and then fully formalized in Brooke, marked the triumph of the Chicago School in United States antitrust law. Evidence in favor of this interpretation is abundant in both decisions. According to the Matsushita Court, predatory strategies are implausible in terms of economic theory because they are unlikely to work and especially costly when failing. It follows that, as McGee had already put it (see above, §2.4), "predatory pricing schemes are rarely tried, and even more rarely successful." ${ }^{138}$ Moreover, given that cutting prices in order to increase business is recognized as "the very essence of competition", it turns out that "mistaken inferences in cases like this one are especially costly, because they chill the very conduct the antitrust laws are designed to protect."139 Therefore, "if

${ }^{134}$ Brooke Group Ltd, 509 US at 242.

${ }^{135}$ Bolton et al, 88 Georgetown L J at 2258-59 (cited in note 23).

${ }^{136}$ Glazer, 62 Antitrust L J at 633 (cited in note 125).

${ }^{137}$ According to Hovenkamp, 41 Antitrust Bulletin, at 836 (cited in note 46), proving that the possibility of recoupment is concrete is tantamount to saying that PP is rational behavior, and thus likely to occur in that specific situation.

${ }^{138}$ Matsushita Elec Indus, 475 US at 589.

${ }^{139}$ Id at 594. 
"the factual context renders respondents' claim implausible-if the claim is one that simply makes no economic sense-respondents must come forward with more persuasive evidence to support their claim than would otherwise be necessary." ${ }^{140}$ The point that validating loose PP accusations would risk deterring pro-competitive behavior is made even more forcefully by the Brooke Court: "As a general rule, the exclusionary effect of prices above a relevant measure of cost either reflects the lower cost structure of the alleged predator, and so represents competition on the merits, or is beyond the practical ability of a judicial tribunal to control without courting intolerable risks of chilling legitimate price cutting. ${ }^{\prime 141}$

As we know well, the central argument of Chicago critique against $\mathrm{PP}$ was at the same time theoretical and practical. Accordingly, the Matsushita Court referred to "a consensus among commentators", quoting in support of its position the full line-up of Chicago antiPP classics, from McGee to Bork, from Koller to Easterbrook, plus the ever-present Areeda and Turner. ${ }^{142}$ From here, it is just a small step to identify as the main inspiration for the many hurdles set in front of a PP accusation by the Brooke Court one of Chicago main "articles of faith."143 I refer to the belief that courts and agencies are very insecure when it comes to policing competition-in other words, that US antitrust law is founded on the principle that market processes are usually superior to legal or administrative processes in the task of allocating scarce resources. Consistently with this strong belief, antitrust law should proscribe only those behaviors that are flagrantly anti-competitive, leaving to other parts of the law (either property, contract or tort law) and to incentive-guided market behavior the protection and enhancement of total welfare. The Court in Matsushita and Brooke simply endorsed this point of view.

It follows that the recoupment test was established as the best functional screen for PP cases. Asking whether recoupment is feasible under the plaintiff's theory of predation is in fact a much simpler question than the-only apparently-straightforward one: "is the defendant's price below an appropriate measure of its cost?"144 Recoupment analysis requires less information than price-cost comparisons because a single finding, such as "other competitors exist"

${ }^{140} \mathrm{Id}$ at 587.

${ }^{141}$ Brooke Group Ltd, 509 US at 223.

${ }^{142}$ Matsushita Elec Indus, 475 US at 589.

${ }^{143}$ D Crane, Chicago, Post-Chicago, and Neo-Chicago, 76 Univ Chic L Rev 1911, 1929 (2009).

${ }^{144}$ Boudreaux et al, 4 S Ct Econ Rev at 72 (cited at note 130). 
or "entry into the market is easy" or "customers may undertake effective counterstrategies", is sufficient to invalidate the test and thus, lead to the summary dismissal of the plaintiff's claim-leaving the final word to the market, in line with the core tenets of Chicago economics.

The irony of Brooke $e^{145}$ is that the Court went so far in its decision and established such a harsh standard that the plaintiff lost the case despite having substantially demonstrated that the defendant had actually engaged in a successful predation strategy. This, according to Glazer, ${ }^{146}$ entailed a very un-Chicago claim of the superiority of the Court's knowledge over that of market participants themselves. Indeed, the Brooke plaintiff accepted the need to prove a plausible recoupment scenario, presented evidence and expert testimony about the objective characteristics of the market showing how the defendant could realistically recoup the losses of the predatory phase designed to discipline his rival, and even relied on documented market analysis by the defendant's own management, showing that the latter materially acted (by investing millions of dollars) on the belief that a predatory campaign would create a reasonable possibility of lessening competition-in short, the plaintiff had provided the Brooke Court with both the "story" and the "intent."147 The fact that it lost anyway means, among other things, post-Brooke courts need no longer defer to the informed judgment of market agents. ${ }^{148}$ This obviously clashes with the above-mentioned "article of faith" for Chicago economics: "the Court's willingness to assume that a sophisticated marketplace actor [the defendant] did not know what it was doing and was, in essence, acting irrationally is actually at odds with the Chicago School's reliance on the wisdom of marketplace actors." 149 So strong was the 1993 Court's persuasion (fully in line with Chicago views) against the validity of PP claims that a finding of violation was precluded, no matter what the evidence might reveal about the defendant's intent and behavior and no matter what

${ }^{145}$ At least according to the admittedly very partial reading of Glazer, 62 Antitrust $\mathrm{L} J$ at 633 (cited at note 125).

${ }^{146} \mathrm{Id}$ at 623.

${ }^{147}$ Id at 625 .

148 "Brooke Group gives courts license to ignore such evidence [about market agents' knowledge] when it conflicts with their own convictions about what will happen in the marketplace. It tells them that they need not be influenced by the marketplace actors themselves." Id at 626.

${ }^{149} \mathrm{Id}$. To add further irony, the plaintiff, in the effort to uphold the relevance of the defendant's beliefs and conduct, relied on the scholarship of no less than Chicago champion Frank Easterbrook: see id at 626, fn 103. 
the decision might entail for the broad issue of where market knowledge actually resides.

\section{KILLING GAMES:PART IIAND III}

The following pages deal with two other possible explanations for the post-1980 Supreme Court jurisprudence on PP cases, and in particular of its failure to take into account the novel ideas coming from game theory and the so-called Post-Chicago approach to antitrust. ${ }^{150}$ These are not intended to deny the validity of the most traditional explanation offered in the previous section, but rather to integrate it, by showing that the straightforward equation "Matsushita \& Brooke = Chicago antitrust law and economics" does not tell the whole story.

A. The first alternative reading is suggested by Bill Kovacic in a 2007 Columbia Business Law Review paper, where he emphasizes the role played in the development of PP antitrust law by three famous Harvard law scholars such as Areeda, Turner and, above all, Stephen Breyer ${ }^{151}$

As noticed before, the recoupment notion had already been briefly mentioned by Areeda and Turner in their 1975 classic, and the paper itself was explicitly mentioned by the Supreme Court among the doctrinal sources of Matsushita. But according to Kovacic, even more influential on the latter decision has been the then-judge Breyer's 1983 ruling in Barry Wright ${ }^{152}$. There Breyer had explicitly endorsed the policy trade-off between the short and long term effects of predation which had animated the post-ATR debate, see above, Section 3.2. Yet, his "standard" concern with the possible deterrence of pro-competitive behavior caused by too strict an enforcement of anti-PP law did not stem in that decision from the same kind

\footnotetext{
${ }^{150}$ This name characterizes an approach to antitrust law and economics that aims at replacing the Chicago School as the leading theoretical engine for the application of economic theory to competition policy and enforcement. The analytical backbone of the Post-Chicago approach is provided by game theory in general, and by AIG in particular. A 1989 paper by Baker is considered the informal manifesto of the approach. J B Baker, Recent Developments in Economics That Challenge Chicago School Views, 58 Antitrust Law J, 645-655 (1989). On Post-Chicago law and economics see A Cucinotta, R Pardolesi and R Van den Bergh, eds, Post-Chicago Developments in Antitrust Law (2002 Edward Elgar); R Pitofsky, ed, How the Chicago School Overshot the Mark (Oxford 2008).

${ }^{151}$ Kovacic, 1 Columbia Business at 1-81 (cited in note 9). A Harvard law professor since 1967 and a judge on the First Circuit Court of Appeals since 1980, Stephen G. Breyer has been appointed in 1994 as Associate Justice of the US Supreme Court.

${ }_{152}$ Barry Wright Corp v ITT Grinnell Corp, 724 F2d 227 (1st Cir 1983). Kovacic, 1 Columbia Business at 48-9 (cited in note 9).
} 
of preoccupations of Chicago economists. It rather came out from the very feeling that had motivated Areeda and Turner in 1975 see above, Section 2, namely, the fear that courts and antitrust agencies often lacked the ability to handle difficult antitrust cases and, consequently, that antitrust law might suffer serious credibility losses from too many unsound decisions. ${ }^{153}$

Kovacic claims that caution about the administrability of rules and the capacity of antitrust institutions to implement them have been the main contributions of Harvard Law School to modern US antitrust. Though sharing the general concern about deterrence effects, ${ }^{154}$ Harvard preoccupation was not identical to Chicago's. While the latter had a theoretical (one would say, ideological) foundation in the alleged superiority of markets in allocating scarce resources with respect to every other institution, the former addressed the practical side of antitrust law enforcement. It follows that the Brooke test may be read, at least in part, as the outcome of Harvard scholars' insistence that competition policy should take into account the limitations of US antitrust institutions, and thus give prominence to a few simple and fully operational principles that all courts and agencies may easily apply. ${ }^{155}$

Kovacic's thesis is confirmed by taking a closer look at Justice Breyer's antitrust doctrine. ${ }^{156}$ First as a judge in the Court of Appeals of the First Circuit and then as a member of the Supreme Court, Breyer has always decided, in antitrust cases, in favor of bright-line rules and safe harbors whenever the benefits of exhaustive anal-

\footnotetext{
${ }^{153}$ In his tribute to the memory of Donald Turner, Breyer wrote that from the mid1960s "it was becoming increasingly apparent that, to create coherent antitrust policy, reliance upon statute, precedent and instinct alone would not work. Unless informed by economics, disciplined with intellectual rigor, and administered with an understanding of industrial practicality, enforcement of the antitrust laws risked uncertainty, economic hardship, and injuring the very consumers they were meant to protect." S G Breyer, 41 Antitrust Bulletin, at 725 (cited at note 29).

${ }^{154}$ The passage of Breyer's Barry Wright quoted by the Supreme Court is indeed that: "[w]e must be concerned lest a rule or precedent that authorizes a search for a particular type of undesirable pricing behavior end up by discouraging legitimate price competition." Matsushita Elec Indus, 475 US at 594.

155 Similarly, Bruce Kobayashi argues that, far from pushing towards an accurate and economically sophisticated measure of the profit sacrifice incurred by an alleged predator, the Court's real purpose in Brooke was to make clear that antitrust enforcers have to accept that their measurement tools are too imprecise to evaluate a firm's business strategy without creating an intolerable risk of deterring pro-competitive behavior. Kobayashi, The Law and Economics of Predatory Pricing (cited in note 113). Here, according to Kobayashi, lies a possible explanation for the failure of sophisticated game-theoretic models to affect US courts' attitude towards PP, a point we will return to in the following pages.

${ }^{156}$ See L B Greenfield and D J Matheson, Rules Versus Standards and the Antitrust Jurisprudence of Justice Breyer, 23(3) Antitrust 87-91 (2009).
} 
ysis, using all the available economic tools, would not justify the costs. Barry Wright is exemplary in this regard. In that ruling Breyer rejected an allegation of "unreasonably low price", establishing a bright-line rule which-in the same spirit of ATR-effectively immunized from antitrust scrutiny any price that exceeded both incremental and average cost, thus providing a major channel for bringing Areeda and Turner's proposal into mainstream antitrust jurisprudence, including the Supreme Court's.

In the same decision, Breyer also rejected a Ninth Circuit test developed in another PP case that admitted that even a price exceeding average total cost could be predatory if it had been used strategically in order to discipline competition. ${ }^{157}$ Crucially, the test was not dismissed via a theoretical argument (say, because price theory proved that pricing above ATC could never harm consumers), but rather on the claim that any rare instance of possible welfare loss caused by such a price did not justify the costs of the fully-fledged rule of reason analysis required to undertake the test. Far from denying that antitrust enforcement could enormously benefit from the insights and rigor of economic theory, Breyer remarked that: "while technical economic discussion helps to inform the antitrust laws, those laws cannot precisely replicate the economists' (sometimes conflicting) views. For, unlike economics, law is an administrative system the effects of which depend upon the content of rules and precedents only as they are applied by judges and juries in courts and by lawyers advising their clients." ${ }^{158}$ These words immediately preceded the famous passage where Breyer argued that he did not want, for the sake of pursuing every economic complexity and qualification, to risk sacrificing the "bird in hand" of above-cost price cuts, surely benefiting consumers in the short run, for the "bird in the bush" of possible lower prices in the long run. ${ }^{159}$ Such a clear vision of the policy tradeoff, inevitable in every PP case, between sure short term gains and potential longer term gains has been very influential in US antitrust jurisprudence. Indeed, themes from Breyer's First Circuit opinions have profoundly affected some of the most significant Supreme Court's antitrust decisions over the last twenty years. ${ }^{160}$

\footnotetext{
${ }^{157}$ Note that, in confirmation of the early development of (informal) strategic arguments, such a Ninth Circuit test actually predated AIG. William Inglis $\oplus$ Sons Baking Co v ITT Continental Baking Co, 668 F2d 1014, 1035 (9th Cir, 1981).

${ }_{158}$ Barry Wright, $724 \mathrm{~F} 2 \mathrm{~d}$ at 234, emphasis added (cited in note 152).

${ }^{159}$ Id.

${ }^{160}$ Starting from the early 1990s, the Court has ruled in favor of defendants in an unbroken line of antitrust case. Several of these decisions adopted a "safe harbor" approach protecting the defendant's conduct that was clearly inspired by the Barry Wright doctrine. For example, the Matsushita Court cited the "bird in hand" prin-
} 
The suggested interpretation finds further support in Breyer's voting pattern as a Supreme Court Justice. An institutionalist perspective on the comparative competence in decision-making and an overall leaning towards technocracy seem to motivate his decisions. For example, in Trinko ${ }^{161}$ he concurred with Justice Scalia's opinion in expressing a preference for regulatory decision making by administrative agencies, rather than antitrust enforcement by generalist judges, on account of the superior competence of the former with respect to the latter. In Leegin, ${ }^{162}$ his dissent in favor of rules rather than standards was motivated on the ground that juries may have difficulty in applying open-ended and economically dense standards.

One may legitimately ask whether Justice Breyer's rule-based antitrust jurisprudence is merely synonymous with pro-defendant. The answer is negative, as Breyer's message in Barry Wright was simply that definite rules should be applied in appropriate casesa message that does not necessarily lead to systematically prodefendant outcomes in antitrust litigations. The real issue upon which Breyer has exercised his enormous influence is that a court's choice between bright-line rules and more open-ended inquiries (aka, stories) should depend on considerations that have nothing to do with the problem of whether a given conduct (say, a price cut) is or is not anti-competitive. As he famously stated in another First Circuit decision: "We shall take into account of the institutional fact that antitrust rules are court-administered rules. They must be clear enough for lawyers to explain them to clients. They must be administratively workable and therefore cannot always tsake account of every complex economic circumstance or qualification."163 What matters most here, Breyer's opinions seem to have little to do with the Harvard vs. Chicago controversy that in so many historical reconstructions represents the main driving force of the evolution of US antitrust law in the last 30-40 years. ${ }^{164}$

ciple to emphasize the dangers of mistaken inferences in PP litigations. The Court then reiterated the same concern in Cargill and, later, in Brooke. Even the controversial-and eventually withdrawn-Section 2 Report by the US Department of Justice (2008), which aimed at harmonizing the DOJ enforcement of anti-monopolization statutes with the most widely accepted legal doctrine and economic theory, echoed many of the themes of Breyer's jurisprudence and quoted Barry Wright more than ten times.

${ }^{161}$ Verizon Communications Inc v Law Offices of Curtis V Trinko LLP, 540 US 398 (2004).

${ }^{162}$ Leegin Creative Leather Products Inc v PSKS Inc, 551 US 877 (2007).

${ }^{163}$ Town of Concord v Boston Edison Co, 915 F2d 17, 22 (1st Cir 1990).

${ }^{164}$ See Crane, Chicago, Post-Chicago, and Neo-Chicago, at 1918-1920 (cited at 143). Concerning Trinko, Kovacic underlines how the ideas contained in Justice Scalia's majority opinion are hardly the outcome of Chicago School thinking alone 
B. The other alternative reading of Matsushita and Brooke hinges upon the internal logic of Supreme Court's decisions. The reconstruction starts in 1984, when the Court argued in Monsanto ${ }^{165}$-a Sherman Act $\S 1$ conspiracy case-that a single piece of circumstantial evidence that could have resulted from either a conspiracy or independent behavior was insufficient for a plaintiff to survive a motion for judgment notwithstanding the verdict. The general principle was that, for a plaintiff to defeat a motion for a directed verdict under a claim of concerted price fixing, evidence had to be presented, either direct or circumstantial, that "tends to exclude the possibility" that the alleged conspirators acted independently. ${ }^{166} \mathrm{In}$ other words, whenever the circumstantial evidence produced by the plaintiff might have been caused by pro-competitive behavior, the Court required that the "tends to exclude" principle be satisfied in order to avoid deterring firms from undertaking a legitimate, proefficiency behavior. ${ }^{167}$

The Monsanto principle reveals that the "avoid chilling competitive behavior" argument pre-dates Matsushita. In his lengthy study of the latter decision, Nickolai Levin notes that the principle itself may well have been the outcome of the rise of Chicago antitrust scholarship, as well as of the Court's Harvard-style desire to employ economics in order to revive and strengthen antitrust law. ${ }^{168}$ Yet, he also underlines that later decisions, such as Matsushita, should be read first and foremost as the Court's effort to delimit and clarify the meaning of the Monsanto principle. In particular, Matsushita should be seen as the effort to extend the principle to a summary judgment context in a PP case. As the Court put it: "To survive a motion for summary judgment or for a directed verdict, a plaintiff seeking damages for a violation of [Sherman Act] $\S 1$ must present evidence that 'tends to exclude the possibility' that the alleged conspirators acted independently. Respondents [... . must show that the inference of conspiracy is reasonable in light of the competing inferences of independent action or collusive action that could not have

(allegedly championed in the Court by Scalia himself) and should be more correctly considered the product of a Scalia/Breyer collaboration. Kovacic, 1 Columbia Business, at 67-8 (cited in note 9).

${ }^{165}$ Monsanto Co v Spray-Rite Serv Corp, 465 US 752 (1984).

${ }^{166} \mathrm{Id}$ at 753 .

${ }^{167}$ "It is of considerable importance that independent action by the manufacturer, and concerted action on nonprice restrictions, be distinguished from price-fixing agreements, since, under present law, the latter are subject to per se treatment and treble damages." Id at 763; also see N G Levin, The Nomos and Narrative of Matsushita, 73 Fordham L Rev 7-1710, 1630 (2005).

${ }^{168}$ Levin, 73 Fordham L Rev at 1630 (cited in note 167). 
harmed respondents." 169 Hence, a new requirement of "reasonable in the light of competing inferences" was developed by the Court, which immediately applied it to the PP case under scrutiny. Cutting prices being the very essence of competition, there obviously existed a possible inference of pro-competitive behavior in the light of the observed price reduction, so much so that the motion for summary judgment could not be survived by the Matsushita plaintiff.

A few lines before the above-quoted passage, the Court had also argued that: "if the factual context renders respondents' claim implausible-if the claim is one that simply makes no economic sense-respondents must come forward with more persuasive evidence to support their claim than would otherwise be necessary." 170 The combination of the two passages leads Levin to read into the new, "reasonable in the light of competing inferences" principle the Court's clarification that the Monsanto "tends to exclude" doctrine also applies to plausible allegations. Even in front of a plausible inference of antitrust violation, there may still exist a pro-competitive explanation for the same behavior.

Levin's remark is crucial for our narrative. Not surprisingly, these two key passages immediately precede the fourth section of Matsushita decision, namely, the pages where the Court openly addressed Chicago scholarship in order to explain why PP schemes had to be considered implausible on the basis of rigorous economic theory. ${ }^{171}$ With the explicit reference to Chicago doctrine, the Matsushita Court set forth a new definition of "reasonableness." "172 Starting from 1986, the term "reasonable" incorporates what Levin calls "a caseexternal dimension", that is to say, the idea that the reasonableness of any specific inference in an antitrust case also depends on how allowing the inference might affect, or deter, market competition in general. It is in this specific sense that Matsushita is commonly said to have established a gate-keeping role for courts in antitrust cases. ${ }^{173}$ Judges and juries are required to assess the reasonableness of plaintiff's inferences and, in doing so, they also have to take into account the external effect on social welfare and market efficiency of admitting, or rejecting, a certain inference.

The new dimension of reasonableness is confirmed by the several Circuit courts which, using the gate-keeping power granted to them by Matsushita, have limited admissible inferences of harmful

${ }^{169}$ Matsushita Elec Indus, 475 US at 587-88, emphasis added.

${ }^{170}$ Id at 587.

171 Id at $589 \mathrm{ff}$.

${ }^{172}$ Levin, 73 Fordham L Rev at 1632 (cited at note 167).

${ }^{173} \mathrm{D}$ A Crane, Rules Versus Standards in Antitrust Adjudication, 64 Washington \& Lee L Rev 49-110, 77 (2007). 
business behavior. ${ }^{174}$ Yet, the interpretation of the joint MonsantoMatsushita principle is still an open issue in American law. Does the "tends to exclude" requirement applies to all antitrust cases? Does it apply only to implausible inferences? Or does it apply only when there is a significant risk of deterring pro-competitive behavior? Take the second ("implausibility only") reading. This would fit nicely with what the Matsushita Court thought of PP stories, inasmuch as, following Chicago doctrine, predation turns out to be a strategy that no rational, profit-maximizing firm would ever pursue. However, following Levin and recalling that the Court verbatim extended the Monsanto principle to plausible inferences, it is the third ("deterrence only") reading that seems more respectful of the Court's decisions, as the latter aimed at establishing a precautionary requirement against the case-external risk of causing welfare losses by chilling pro-competitive behavior. ${ }^{175}$

${ }^{174}$ For a partial list of PP cases see Crane, 64 Washington \& Lee L Rev at 78 \& fn 122 (cited in note 173). Crane notes that the gate-keeping role has been mainly exercised in cases involving the application of per se rules, first and foremost PP cases.

175 The latter reading may also account for the Supreme Court decision in Eastman Kodak Co v Image Technical Services Inc, 504 US 451 (1992). In Kodak-a tying case-the Court seemingly sided with Post-Chicago in that it argued that imperfect information alone may suffice to destroy an otherwise competitive market, thereby somehow equating imperfect information to other, more traditional anti-competitive features, such as a big market share. R H Lande, Chicago Takes it on the Chin: Imperfect Information Could Play a Crucial Role in the Post-Kodak World, 62 Antitrust L J 193-202, 194-95 (1993). Levin reinterprets Kodak as an outcome of the Court's internal logic, in particular of its effort to clarify the extent of the Monsanto/Matsushita principle. According to him, the Kodak Court just gave a specific solution to the procedural issue left open by Matsushita, namely, "how often" an observed business behavior had to be pro-competitive in order to trigger the inference limitation of the original Monsanto principle and thus lead a court to "shut the gate" in the plaintiff's face. The answer was that it was not sufficient for the behavior to be generally more favorable than harmful to competition, because, as the Kodak Court stated, the Monsanto principle of limitation could only be invoked when the behavior was "always, or almost always" pro-competitive. Levin, 73 Fordham L Rev at 1632 (cited at note 167). Remarkably for our narrative, the Court considered cutting prices to be precisely one such case, and thus classified PP as a paradigmatic example of-to borrow Levin's term-theoretical implausibility, i.e., of an inference that might even be factually plausible were it not for current economic theory clearly indicating that it was very unlikely correct. Id at 1695. Levin's interpretation also leads to a new reading of Brooke (see main text), as this decision would represent the Court's solution to the new issues raised by Kodak. In any case, and regardless of Levin's reconstruction, much of the bolder Post-Chicago claims triggered by Kodak have been watered down in the following years by lower courts. D A J Goldfine and K M Vorrasi, The Fall of the Kodak Aftermarket Doctrine: Dying a Slow Death in the Lower Courts, 72 Antitrust L J 209-231 (2005). For a different way Kodak may still help the game-theoretic approach to PP see Bolton et al, 88 Georgetown L J at 2000, 2265 (cited in note 23). 
In terms of Levin's interpretation, it came naturally that Brooke's hallmark, the recoupment test, established a sharp differentiation between PP and every other instance of exclusionary conduct. In the latter, the inference of injury to competition may be drawn by simply looking at the conduct itself and at market structure. In predation cases - and only in them-a further requirement must be satisfied. The fact that an accusation of PP was seen by the 1993 Court as the only instance of "investment in the creation of market power" by a dominant firm that called forth a much tighter standard of proof, may thus be read as the Court's willingness to clarify that PP cases epitomize precisely that danger of deterring virtuous marketplace behavior. Hence, rather than embodying the judicial byproduct of any epic clash amongst competing law and economics schools (Harvard, Chicago, Post-Chicago), the whole sequence Monsanto-Matsushita-Brooke ${ }^{176}$ would simply represent the physiological outcome of the evolution, and clarification, of the Supreme Court's antitrust jurisprudence. ${ }^{177}$

Another, more recent decision seems to further corroborate this sequence. In Twombly, an antitrust conspiracy case, ${ }^{178}$ the Court transplanted its Matsushita principle concerning summary judgment standards to a motion to dismiss for failure to state a claim. Under the procedural standard set forth in Conley, ${ }^{179}$ a complaint need only state facts that made it "conceivable" that it could prove its legal claim. This meant that a court could only dismiss a claim if it appeared, beyond any doubt, that plaintiffs would be able to prove "no set of facts" in support of their claim. The Twombly Court reneged this principle, stating that plaintiffs must allege "enough facts to state a claim to relief that is plausible on its face ${ }^{\prime \prime}$, i.e., that their claims must be capable to "[c]ross the line from conceivable to plausible." 180 In the specific case under scrutiny, the Court argued that the complaint could not be based on mere allegations of parallel

${ }^{176}$ A sequence to which, according to Levin, Kodak should also be added. See the previous note.

${ }_{177}$ One may legitimately ask why the Brooke Court did not make one step further and establish the per se lawfulness of every price cut by non-collusive firms. For example, Boudreaux, Elzinga and Mills argue that, following the Supreme Court's own justification of per se rules (i.e., that rules should be preferred to standards whenever the risk of possible welfare losses are clearly outweighed by the sum of potential gains plus the sure savings of administrative costs), Brooke should have contained a rule legalizing price cuts. Boudreaux et al, 4 S Ct Econ Rev at 76-8 (cited in note 130); Brooke Group Ltd v Brown e) Williamson Tobacco Corp, 509 US 209 (1993).

${ }_{178}$ Bell Atlantic Corp v Twombly, 550 US 544 (2007). I thank one of the referees for having directed my attention to this further element of the sequence.

179 Conley v Gibson, 335 US 41 (1957).

180 Twombly, 550 US at 570. 
conduct because the plaintiff was required to set forth a factual context which would allow truly unlawful behavior, i.e., conspiracy, to be distinguished from lawful one, i.e., parallel independent action.

The decision has triggered a vast debate about the reduced accessibility to the legal system for plaintiffs who might be forced to incur uncompensated, fact-finding costs prior to filing suit. ${ }^{181}$ But even in the more limited realm of antitrust law the impact of Twombly is potentially huge. ${ }^{182}$ The Matsushita Court had stated that if the plaintiff cannot reasonably exclude the possibility that the defendant was acting legally, the judge should not let the case go to the jury. Yet, in that decision the plaintiff had still been granted the opportunity to conduct discovery. In the effort to avoid those expensive "fishing expeditions" for discovery which may make Sherman Act private litigations especially burdensome, the Twombly Court decided to raise the bar for antitrust plaintiffs, thereby reducing the room for costly private antitrust lawsuits. ${ }^{183}$ Avoidance of litigation per se was considered by the 2007 Court a sufficiently worthy goal to restrict court access to plaintiffs by explicitly requiring that antitrust complaints must be endowed with factual enhancement in order to cross the line between possibility and plausibility. This not only on account of the high costs of antitrust discovery, but also because of the concern for the potential chilling effects on competitive behavior which may descend from allowing private plaintiffs too easily a recourse to antitrust lawsuits. ${ }^{184}$ The requirement of fac-

${ }^{181}$ See, for example, Epstein, 2011 (1) U Ill L Rev at 187-213 (cited in note 129) and the literature and case law cited therein.

${ }^{182}$ Two articles, by Keyte and by Anderson and Huffman, show how the Twombly principle has been applied to the pleading standards of every type of antitrust claims. J A Keyte, Twombly: How Courts are Interpreting and Extending its Principles, 23 (Fall) Antitrust 65-71 (2009); M Anderson and M Huffman, Iqbal, Twombly, and the Expected Cost of False Positive Error, 20 Cornell J L \& Pub Pol 1-66 (2011).

${ }^{183}$ See R C Picker, Twombly, Leegin and the Reshaping of Antitrust, John M. Olin Law \& Economics Working Papers, Univ of Chicago, at 4 n.389 (2008). The decision may be criticized in that it seems to neglect that for several antitrust violations the complaint may, almost by definition, offer little more that the plaintiff's belief that the defendant behavior was illegal. Given that the defendant's intent, in a conspiracy case, or his production costs, in a predation case, are always private information, this belief may only be confirmed if discovery is allowed. Id at19. To this critique, Richard Epstein has countered that the Twombly principle empowers courts to dismiss only factually implausible complaints, i.e., only the limited subset of antitrust cases where actual discovery would really make no sense. As an example of the latter, Epstein mentions PP because these are cases where a well established set of "generic facts" (i.e., those stemming from standard economic theory) weigh heavily against the complaint. Epstein, 2011 (1) U Ill L Rev at 196-97 (cited in note 129).

${ }^{184}$ See Twombly, 550 US at 544 (section III of the opinion), and Anderson and Huffman, 20 Cornell J L \& Public Policy at 18-19 (cited in note 182). 
tual plausibility, plus the latter case-external concern, show that, from the antitrust perspective, Twombly may well be viewed as the continuation of the Monsanto-Matsushita-Brooke sequence.

\section{A GAME SAVER?}

In the previous Sections we have offered three possible explanations for Brooke. Yet, regardless of whether the decision should be seen as a manifestation of the triumph of Chicago School price theory, as an outcome of a Harvard-style concern for administratively feasible rules, as an application of the Monsanto/Matsushita principle of reasonable inferences-or probably as the result of all of the three combined-the fact remains that since 1993 no plaintiff has ever won a PP case at federal court level. ${ }^{185}$ This is highly significant given the recent trend in US antitrust courts to favour standards over rules, ${ }^{186}$ although the Brooke principle itself may not be depicted as purely rule-like, but rather as a combination of a rule-like part (the pricecost rule) and a standard-like part (the recoupment test, entailing a structural analysis).

Yet, a few Industrial Organization (IO) economists did not let Brooke go unchallenged. What they could not accept was the Supreme Court's endorsement of Chicago-style price theory at a time when the game-theoretic approach was replacing it as the hard core of mainstream economics in general, and of modern IO in particular. Historically speaking, the critique was well taken. Indeed, it may be argued that even before the game-theoretic revolution Chicago price theory had never achieved the same status and success in economics that it has enjoyed in the courtrooms. According to leading IO economist Stephen Martin, economics in general, and industrial economics in particular, never considered Chicago so-called "tight prior equilibrium method" and its implication, the static, non-strategic approach to competition, as mainstream. Far from representing the method of economic theory, Chicago economics has always been viewed by non-Chicagoans as an idiosyncratic version of the neoclassical theory of perfectly competitive markets, of hardly any utility in the analysis of imperfect competition and antitrust. Surely,

\footnotetext{
${ }^{185}$ Of particular import among recent decisions is the summary judgment against the Department of Justice in U S V AMR Corp, 335 F 3d 1109 (10th Cir 2003). The judgment came on account of the government's inability to meet the requirements of Brooke. Moreover, the government's reputation theory of predation was explicitly dismissed at district court level as "subjective and unverifiable". See Crane, 64 Wash \& Lee L Rev at 71 (cited in note 173); G Monti, EC Competition Law 72-73 (Cambridge 2007).

${ }^{186}$ Crane, 64 Wash \& Lee L Rev (cited in note 173).
} 
since the mid-1980s, the advent and quick rise to dominance of game theory set the record straight in the marketplace of ideas: strategic reasoning has become the way of doing IO analysis. Still, in the last three decades most US antitrust courts have taken Chicago views as representative of the whole IO community. In the subfield of PP, and at the highest judicial level, this attitude is epitomized by the Brooke decision.

In reaction to that attitude, a landmark paper by economists Patrick Bolton and Michael Riordan, and law scholar Joseph Brodley, has tried to re-propose the case for the game-theoretic approach to PP in a way that could make it acceptable to US courts. ${ }^{187}$ The central question is how to solve the tension between legal decisions, like Brooke, and the outcomes of modern economics. BBR correctly identify the main reason behind the judicial skepticism about PP in the assumption of perfect information underlying the kind of economic models which, more or less explicitly, courts seem to follow when deciding over predation charges. ${ }^{188}$ As we know, the assumption was typical of the static, non-strategic approach to PP that led the way until the late 1970s. According to BBR, US courts still adhere to this approach, wrongly believing that it still mirrors the economists' consensus. What these courts-including the Brooke Supreme Courtseem to ignore is that such a consensus does not exist anymore (if it ever existed at all), because modern IO models are, at the same time, more sophisticated and more realistic in that they assume imperfect information and build around it plausible predation stories based on strategic and intertemporal considerations. ${ }^{189}$

Consistently with this view, BBR offer a new, more general and strategic-oriented definition of PP as "a price reduction that is profitable only because of the added market power the predator gains from eliminating, disciplining or otherwise inhibiting the competitive conduct of a rival or potential rival. [. . .] a predatory price is a price that is profit-maximizing only because of its exclusionary or other anti-competitive effects." 190 Yet, they also admit that this and similarly economics-based definitions are not operational in terms

${ }^{187}$ S. Martin, Remembrance of Third Past: Antitrust, Ideology, and the Development of Industrial Economics, 282 Contributions in Econ Analysis 25(2007). Bolton et al, 88 Georgetown L J at 2255-56 (cited in note 23) (BBR henceforth).

188 Id at 2249.

${ }^{189} \mathrm{Id}$. Note once more the emphasis on the higher realism of game-theoretic models of PP-hardly an innocuous claim if only we consider the kind of rationality requirements agents in those games are assumed to possess and apply. See above, section 6 .

${ }^{190}$ Id at 2242-43. 
of applicable legal rules. Hence, they propose a five-step approach that aims at being, at the same time, i) faithful to modern IO economics, ii) consistent with Brooke doctrine, and iii) fully operational in the courts.

Following Joskow and Klevorick's 1979 article $^{191}$, the five steps are divided in two tiers. The first tier, which operates as a screening device, contains three steps: 1) prove the existence of a market structure facilitating $\mathrm{PP}, 2$ ) prove the plausibility of a predation scheme, 3) prove the probability of recoupment. Only when the first-tier scrutiny has given positive answers to all of the three steps, the court should move to the second tier, which requires more exacting proofs: 4) prove that price is below cost, 5) prove there is no efficiency defense justifying the predator's behavior. ${ }^{192}$ The advantage of a two-tiered approach is that, in the same spirit of Brooke, it allows cases to be eliminated via the examination of less resourceconsuming factors, i.e., before requiring expensive evidence for the firm's costs or its efficiency justifications. Moreover, the three steps in the first tier are consistent with the necessary conditions for a PP trial established by the Brooke Court. ${ }^{193}$

The most important steps for us are the second and the third. According to Brooke, to prove PP and recoupment, the plaintiff must show that predation is plausible ex ante and probable ex post, see above, Section 6. BBR argue that ex ante plausibility may be demonstrated by proving the existence of a predatory scheme, i.e., by giving enough evidence supporting a credible story of predation. ${ }^{194}$ But, where can the plaintiff look for such a story? BBR's answer is straightforward: modern game theory has provided a whole playbook of possible predatory schemes. Hence, a plaintiff providing evidence in support of one of those strategic stories could legitimately claim that her argument rests on the rigorous foundations of mainstream economics. ${ }^{195}$ As to ex post probability, BBR argue that it may be maintained by proving either that one or more rivals have

${ }^{191}$ Joskow and Klevorick, 89(2) Yale L J at 213-270 (cited in note 40).

${ }^{192}$ Defendants would obviously bear the burden of proof in this last step.

${ }^{193}$ Bolton et al, 88 Georgetown L J at 2264 (cited in note 23).

${ }^{194}$ This is in the same spirit of Thomas Kauper's "could test": go on with the trial in search of facts only when economic harm could possibly occur, i.e., only when a plausible, theoretically-sound story exists to explain it. T E Kauper, Antitrust in 1992: The Year of the Storyteller, 61 Antitrust L J 347, 348-49 (1993). Yet, it is debatable whether any game-theoretic story of PP may satisfy the Monsanto-Matsushita "tends to exclude" principle as well as the Twombly rule (see above at Section 8.2). More on this below, Section 10.

${ }^{195}$ Bolton et al, 88 Georgetown L J at 2266-67 (cited in note 23). 
been excluded from the market or at least that post-predation market conditions exist that make future recoupment likely. In order to prove the latter, BBR suggest a cost standard, like Baumol's AIC, or Joskow and Klevorick's AAC. ${ }^{196}$

The philosophy behind BBR's proposal is clear. The only way to reconcile modern economics with current legal doctrine is to go back to a rule of reason approach, yet policed by a cost rule. ${ }^{197}$ The element of novelty comes in the way rule of reason analysis should be undertaken. Rather than chasing evidence about the ambiguous notion of predatory intent, the analysis should be guided by, and search for, the elements of one of the PP stories told in the gametheoretic literature. This would capture what the authors consider a peculiarity of predation as an antitrust violation, namely, its being too multi-faceted a phenomenon to be identified by a single factor or behavior (say, a single cost rule). In the spirit of Schmalensee's 1979 contribution $^{198}$, they plead for a case-by-case analysis, capable every time of selecting the particular economic model that happens to fit the factual circumstances of the specific case. ${ }^{199}$

Note however that, as Milgrom and Roberts before them, BBR also err by identifying McGee's 1958 article as the theoretical pillar of the exceedingly lenient, if not entirely laissez faire, approach followed by US antitrust courts in PP cases: "For a long time, McGee's analysis provided the only coherent economic theory of predatory pricing. While some resisted McGee's conclusion that predatory pricing was irrational, no rival theory emerged." 200 This statement is clearly instrumental to BBR's thesis that the real problem behind so many pro-defendant decisions is strictly theoretical and that this problem may be solved only by summoning in the courtrooms a better kind of theory, namely, game theory. But we already know that, far from ever being "for a long time" the "only coherent economic theory" of PP, McGee's analysis was even less accepted by the courts, that almost completely ignored it. BBR themselves betray their own statement, as they claim that what they call "the populist era of pred-

${ }^{196} \mathrm{Id}$ at $2271-72$. Therefore, as far as the recoupment step is concerned, BBR's proposal brings us back to the old price-cost stuff. One may legitimately wonder how to reconcile this aspect of their proposal with AIG's strong claim that predator's costs have no relation whatsoever with the profitability of predation (or, for that matter, with their own claim that one of the weakest aspects of Brooke was the absence of any strategic, not cost-based view of recoupment).

${ }^{197}$ Again the analogy with Joskow and Klevorick is apparent. Joskow and Klevorick, 89(2) Yale L J at 213-270 (cited in note 40).

${ }_{198}$ Schmalensee, 127(4) U Pa L Rev at 994-1050 (cited in note 40).

${ }^{199}$ Bolton et al, 88 Georgetown L J at 2252 (cited in note 23).

${ }^{200}$ Id at 2244. 
atory pricing enforcement" ended abruptly not because of McGee's paper, but rather because of Areeda and Turner in 1975. ${ }^{201}$ Given the Harvard affiliation of both Phillip Areeda and Donald Turner, it is rather curious that $\mathrm{BBR}$ attribute them the triumph of Chicago price theory in the courts.

More than a historical quibble is at stake here. By emphasizing the purely theoretical foundations of the mistaken doctrine followed by post-1975 courts, BBR seem to neglect the main reason behind ATR's success, namely, its being a simple and fully operational rule. In other words, that it was not McGee, but rather Areeda and Turner who really turned the tables in PP enforcement, did not depend on analytical issues-or, for what it's worth, on the Chicago vs. Harvard controversy-but first and foremost on the courts' eagerness to adopt a bright-line rule capable of restoring the credibility of antitrust enforcement, after so many years of discredited PP jurisprudence. In this respect, the Brooke doctrine simply put an authoritative-and long overdue_-seal upon a well established attitude.

The implications of BBR's incomplete reconstruction are severe. If the real motivation behind the new post-1975 attitude of US courts was practical, rather than theoretical, doubts may be raised about the concrete chances of BBR's appeal to the "right" theory-i.e., AIG - to persuade courts to modify their approach. If what judges and juries long for are simple, ready-to-use rules, any proposal calling for a return to fully-fledged rule of reason analysis, including the necessity to trace the evidence supporting complicated stories of strategic predation, is condemned to irrelevance regardless of its own theoretical merits. This kind of mistake has frequently spoiled the PP literature. For example, we know that some of the critics of ATR committed it, though others did not (see above, Sections 3.2-3). It is the same mistake made by the early generation of AIG theorists, though again more acute authors like Milgrom and Roberts were somehow aware of it (see above, Section 6). Above all, it is the very mistake that most clearly accounts for the failure of game theory to have any effective influence upon PP legal doctrine. It wouldn't take long for the critics of the game-theoretic approach to IO and predation to point this out.

\section{JUDGES DON'T PLAY-SHOULD THEY?}

The reaction to BBR's proposal was almost immediate. University of Virginia economists Kenneth Elzinga and David Mills penned a spicy reply where they declared that: "Although strategic theories of

${ }^{201}$ Id at 2250. 
predatory pricing are exemplary in their coherence and rigor, their potential to add value to antitrust policy is much more modest than [BBR] admit." ${ }^{202}$ What game theorists have achieved, they explained, is to identify sufficient conditions for complete and internally consistent stories to elucidate why a rational firm endowed with monopoly power may profitably undertake PP. But this means that the strategic approach is complementary, rather than alternative, to standard price theory. No author working in the latter tradition has ever argued that PP is always irrational, but only that the conditions making it a profitable business strategy are quite improbable, as well as that the means to detect this kind of violation would be overtly expensive and difficult to apply. ${ }^{203}$

It is true that game theory does manage to reformulate some of the existing loose stories of PP and give them more consistency and plausibility. Yet, the predictions stemming from such reformulations are far too sensitive to the underlying assumptions. As Elzinga and Mills put it, the new PP stories may apply only to "factual situations that fit the theory's stringent requirements." ${ }^{204}$ Hence, we are back to step one, because in order to apply these stories, courts need to first prove facts supporting them. For example, a court would have to first show that the asymmetry in either information or financial resources-necessary for a dominant firm to prey upon the rival by successfully muddling its beliefs-actually exists in the evidence. But this is exactly what price theorists have always conceded (e.g., the deep pocket story).

Strategic stories only make things worse in this respect. Firstly, because they impose a higher standard of judging given the intrinsic fragility of their prescriptions (just think of how game equilibria may drastically vary as a consequence of slight variations in the assumptions). BBR simply fail to "acknowledge that proving a more demanding theory calls for a more discriminating factual inquiry. ${ }^{\prime 205}$ Secondly, because the key assumption of many of these models which must be empirically proven, namely, the informational asymmetry (the "incumbent-know-best assumption", as Elzinga and Mills call it), is actually unobservable or unverifiable. ${ }^{206}$

${ }^{202}$ K G Elzinga and D E Mills, Predatory Pricing and Strategic Theory, 89 Georgetown L Rev 2475 (2001).

${ }^{203}$ Id at 2476.

${ }^{204}$ Id at 2477.

${ }^{205} \mathrm{Id}$ at 2475 .

${ }^{206}$ Id at 2478. However, Elzinga \& Mills, recognize that other game-theoretic models exist where equilibrium predation may ensue without assuming any asymmetry at all. See for example the learning curve model by L Cabral and M Riordan, The Learning Curve, Predation, Antitrust, and Welfare, 45 (2) J Indus Econ, 155-169 (1997). 
Thirdly, one should also be skeptical about the overly simplified market structure underlying all game-theoretic models of PP, where the asymmetry between firms is magnified ad hoc. Again, while a PP story may well be plausible in a stylized market, it may not necessarily be so in more complex settings, closer to the real world..$^{207}$

BBR's proposal also looks questionable from the procedural side. According to its supporters, a plausible game-theoretic story, supported by some ex ante evidence on market structure and the likes, should suffice to prove predation in a court, with little if any role left for ex post-i.e., after the price cut-evidence. Yet, one might legitimately wonder what BBR would suggest when the market structure and performance do not fit ex post the ex ante inferences of injury to competition. This, according to Elzinga and Mills, is actually what happened in crucial cases, where either the FTC's or the Supreme Court's cautious behavior with respect to PP allegations, has been vindicated by ex post market developments. ${ }^{208}$ Among these cases features "the poster child for the game theoretic approach" to predation, i.e., the 1984 General Foods coffee case ${ }^{209}$ where ex post data clearly showed that "had game theoretic interpretations persuaded the FTC to restrain [General Foods]'s aggressive pricing, coffee drinkers and competition would have been injured, not the other way round. ${ }^{\prime 210}$

Elzinga and Mills conclude that the prescriptions stemming from the game-theoretic approach have no general analytical value and little practical usage: "Strategic theories of predatory pricing are pristine theoretical existence proofs. Their value lies in identifying sufficient theoretical conditions for predatory pricing to arise as an equilibrium outcome." 211 The new models answer the question: "When, as a matter of economic theory, can predatory pricing occur?", but this is not the relevant question antitrust courts have to answer-the latter actually being, firstly, "Under market conditions actually observed, is predatory pricing the most plausible explanation for an episode of low prices?", and, secondly, "Are these conditions distinguishable from legitimate competition in the market?"212 As these questions clearly show, enforcement of PP law is a practical issue of "is", not the theoretical issue of "can".

${ }^{207} \mathrm{Id}$.

${ }^{208} \mathrm{Id}$ at 2486.

${ }^{209}$ General Foods Corp, 103 FTC 204 (1984). The case is taken as exemplary by both Bolton et al, 88 Georgetown L J at 2255-56 (cited in note 23) and Milgrom and Roberts, 27 J Econ Theory at 280-312 (cited at note 91).

${ }^{210}$ Elzinga and Mills, 89 Georgetown L Rev at 2489 (cited at note 202).

${ }^{211}$ Id at 2493-94.

${ }^{212}$ Id at 2479. 
We devoted so much room to Elzinga and Mills's paper because it is exemplary of the empirical and theoretical objections raised by economists and law scholars against the strategic approach to PP. Their critique concerning the unobservability or unverifiability of the crucial "incumbent-know-best" assumption aptly summarizes the doubts raised in the literature about the alleged higher realism of game-theoretic models with respect to price-theoretic ones. Other examples in this vein ${ }^{213}$ are the scepticism about the heavy burden of rationality required for firms to calculate their equilibrium strategies or the concern about the extreme fragility of the equilibrium itself, symbolized by the Folk Theorem for AIG (see Section 6). The theorem's thesis that there always exists a context (formally, a set of beliefs) supporting a given equilibrium-say, a predatory onemakes the whole approach too ad hoc and therefore hardly acceptable in courtrooms.

To reiterate the point, game theory cannot suggest the certainty, or even the plausibility, of a certain outcome, but just its logical possibility. ${ }^{214}$ As Sam Peltzam noted when reviewing the 1989 Handbook of Industrial Organization, what game-theoretic IO models amount to is "an almost interminable series of special cases", whose conclusions "tend to be very sensitive to the way problems are defined and to the assumptions that follow." ${ }^{215}$ This is a boon in view of the freedom and flexibility it grants to researchers, but an indictment in terms of actual courtroom applicability. The very same flexibility of strategic models that lies behind their enormous success in modern academic IO makes them less apt to produce robust predictions, and thus, eventually explains their inability to influence antitrust courts. ${ }^{216}$

\footnotetext{
${ }^{213}$ Recall that these objections were first raised by Milgrom and Roberts themselves: see above, Section 6.

${ }^{214}$ Also see B H Kobayashi, Game Theory and Antitrust: A Post-Mortem, 5 GMU L Rev 411, 418-19 (1997). That modern economic models too often amount to sheer "possibility proofs", i.e., non-constructive arguments showing just the logical possibility of a certain outcome, is a problem that goes well beyond the boundaries of $\mathrm{IO}$, let alone PP theory. This is not the proper place to investigate more deeply such a delicate issue but see, in a similar vein, N Giocoli, In the Sign of the Axiomatic Method: Mathematics as the Role Model for Neoclassical Economics (Blanqui Lecture), 144-45 in R Arena, S Dow and M Klaes, eds, Open Economics: Economics in Relation to Other Disciplines, 127-147 (2009).

${ }^{215}$ S Peltzman, The Handbook of Industrial Organization: A Review Article, 99(1) J Pol Econ 201, 206 (1991).

${ }^{216}$ Kovacic and Shapiro note that the only way a court can tell whether in a given case a certain business behavior is welfare improving or welfare reducing is to conduct a fully-fledged rule of reason analysis-hardly a progress with respect to what 1960s antitrust practitioners already knew. W E Kovacic and C Shapiro, Antitrust
} 
The move from classrooms to courtrooms is particularly troublesome in the case of imperfect or incomplete information models, like AIG ones, which require some structure on the beliefs of the market participants. There is a whole set of stories an antitrust economist may always tell in her court testimony, each corresponding to a specific belief structure of the competing firms, with little or no factual element to pick the "right" one for the case at hand. Starting from rough details of the firms' behavior, AIG models yield many potential equilibrium outcomes, with no clear way to choose among them. Thus, even the most basic antitrust issues have no clear outcome in a Post-Chicago model. Anything goes in the AIG world. ${ }^{217}$

\section{CONCLUSION: LAW IS NOT A PLA Y R OUND}

In a 1989 article, ${ }^{218}$ MIT economist Franklin Fisher distinguished between generalizing and exemplifying theories. The former are those which proceed from wide assumptions to inevitable consequences and that speak in terms of what must happen given the background circumstances; the latter are those which focus on determining what can happen and are highly sensitive to the assumptions used. ${ }^{219}$ As Fisher himself recognized, oligopoly theory belongs to the exempli-

Policy: A Century of Economic and Legal Thinking, 14(1) J Econ Perspectives 43-60, 55 (2000).

217 The chances that such a world might fare well within the US antitrust system-little as they were-have been further decreased by the same Supreme Court that delivered the Brooke decision. In the famous Daubert case the Court established the principle that to be admitted in court an expert testimony must be not only "relevant", but also "reliable". Daubert v Merrell Dow Pharm Inc, 509 US 579 (1993). The doctrine-which applies to any kind of scientific, technical or other specialized knowledge, including economic knowledge-has significantly restricted the scope for expert testimony, entitling courts to a gate-keeping function with respect to the admission of scientific experts. According to Coate and Fischer, Daubert has doomed the Post-Chicago approach because it has made courts very skeptical about gametheoretic claims when no further evidence is provided relating the challenged conduct to actual market facts or when those facts are indistinguishable from the results of pro-competitive behavior. M B Coate and J H Fischer, Can Post-Chicago Economics Survive Daubert?, 34(4) Akron L Rev, 795-852 (2011). Langenfeld and Alexander offer some data on the "survival rate" of economists' expert testimonies in antitrust cases following a Daubert challenge. J Langenfeld and C Alexander, Daubert Challenges of Antitrust Experts, AAI Working Paper, American Antitrust Institute, n.08/06 (2008).

${ }^{218}$ A mini-classic whose relevance is hard to underestimate (this paper's title is a tribute to it).

${ }^{219}$ F M Fisher, Games Economists Play: A Noncooperative View, 20 (1) RAND J Econ 113-124, 117 (1989). 
fying category; a lot of different things may happen in an oligopoly model and there is no full theory of what must happen given welldefined and measurable circumstances. Hence, he argued that oligopoly theory was simply a collection of "a large number of stories, each one an anecdote describing what might happen in some particular situation." ${ }^{220}$ Fisher added that the advent of game theory had only made things worse in this respect, because the only generalizing result had been a negative one, namely, the Folk Theorem, which "tells us that we cannot hope for a general oligopoly theory based only on cost and demand functions and free of the context in which oligopolists operate." ${ }^{221}$

In the light of Fisher's distinction, and of our analysis in the previous Sections, it turns out that the answers to the three basic questions of $\mathrm{PP}$-does it exist theoretically? is it profitable? is it real? (see Introduction) - provided by the Post-Chicago game-theoretic approach are unable to achieve the status of a generalizing theory, i.e., of the only kind of theory that may find hearing in a US antitrust court, especially after Brooke.222 Therefore, we may claim that the real motivation for the courtroom failure of strategic models of PP is to be found in the irredeemable inconsistency between the exemplifying theories proposed by contemporary IO economists and the kind of arguments considered acceptable by judges or juries. No amount of rigorous theorizing showing the profitability of predatory behavior, nor the empirical observation of successful predatory episodes, have managed to modify the legal response to PP, which has remained faithful to the operational imperative of a relatively administrable "bright line" rule, provided of course the rule itself be based on-to borrow the Supreme Court's famous Daubert dictum-"relevant and reliable science". What the Supreme Court did in its 1993 Brooke decision was therefore not to provide any sophisticated yardstick for assessing PP, but rather to proclaim the inherent difficulty and imprecision of any such assessment, and with it the dubious scientific status of any theoretical claim supporting the existence and profitability of predatory behavior.

It is now customary to place Brooke within the Supreme Court's more general drive, going on throughout the 1990s and still continuing today, to "fix the Court's antitrust" by realigning its doctrine to the findings of modern IO. ${ }^{223}$ According to the standard narrative, the

220 Id at 118 .

${ }^{221} \mathrm{Id}$.

${ }^{222}$ And Daubert and, more recently, Twombly.

${ }^{223}$ On this general trend see E Elhauge, Harvard, not Chicago: Which Antitrust School Drives Recent Supreme Court Decisions, 32 (2) Competition Policy Int 159 (2007); Werden, 5(1) J of Competition L \& Econ at 49-74 (cited in note 20). 
strategic turn of IO, with the rise of the Post-Chicago approach, has been the inevitable reaction from those economists who, against the courtroom triumph of the laissez faire Chicago approach, employed game theory to rescue and, at the same time, strengthen with more rigorous foundations some of the old Harvard antitrust mantra prohibiting several of the most typical conducts by dominant firms. In this story, the Brooke decision would simply be representative of all those courts that still stick to Chicago price theory, unaware that this approach has long lost its central status within mainstream economics.

As I have attempted to show, this reconstruction is plausible, but at best incomplete. To begin with, asking whether the Brooke Court was following Harvard or Chicago is a false problem-or, if you like, a trivial one, since the only correct answer is "both". This because both approaches entail faithfulness to the simple rule-based view of antitrust enforcement in general, and of PP enforcement in particular. It is standard price theory, the common ground of both approaches, which imposes adherence to this view. On the contrary, game-theoretic IO points in the opposite direction, i.e., away from simple, mechanical rules and back to a story-based assessment of every predatory case. Hence, the real dichotomy that should be investigated is not Harvard versus Chicago, but rather rules versus stories. ${ }^{224}$

Once the terms of the question have been properly identified, we may explain why, starting from the mid-1970s, most US antitrust courts, and principally the Supreme Court, have expressed a clear preference for a rule-based approach to predation cases, thereby killing any concrete chance for the game-theoretic methodology to gain any hearing in the courtroom. The history of PP law and economics shows that, at the end of the day, it is the legal argument-rectius, the legal attitude with respect to a certain way of presenting an argument-which prevails, rather than the rigor or elegance of one economic theory to another. Quoting Tom's 1997 article: "The outcomes of particular formal models may be less important than the tendency of the game-theoretic perspective to reinforce the litigator's traditional emphasis on 'the story' at the expense of the appellate judge's traditional emphasis on 'the rule' ${ }^{\prime \prime}, 225$ and it goes without saying which of the two emphases is destined to prevail in courtrooms.

${ }^{224}$ See Crane for a general assessment of this dichotomy. Crane, 64 Wash \& Lee L Rev at 49-110 (cited in note 173). Note that the "safe harbors" approach, a hallmark of Chicago antitrust, is just a different name for a pro-defendant, rule-based approach.

${ }^{225} \mathrm{~W} \mathrm{~K}$ Tom, Game Theory in the Everyday like of the Antitrust Practitioner, 5 GMU L 457-469 (1997). 
As to the reason why courts may prefer simple rules to more flexible, but also more complicated, stories, it is apt to go back to Breyer's 1990 dictum in Town of Concord: "We shall take into account of the institutional fact that antitrust rules are court-administered rules. They must be clear enough for lawyers to explain them to clients. They must be administratively workable and therefore cannot always take account of every complex economic circumstance or qualification." 226 The price for being consistent with such an obvious truth has been that, as an authoritative commentator and former FTC associate director put it, "[i]n the one area in which economists' game-theoretic approaches seemingly offered new possibilities for plaintiff victories-predatory pricing-the post-Chicago approach has failed to deliver." 227 A very low price, at least for antitrust judges and juries. Indeed, so low that it has allowed the Chicago predator to defend its leadership in the US courtroom "market" at the expense of the Post-Chicago prey. 
Copyright of Supreme Court Economic Review is the property of University of Chicago Press and its content may not be copied or emailed to multiple sites or posted to a listserv without the copyright holder's express written permission. However, users may print, download, or email articles for individual use. 